\title{
The Himalayan Cryosphere: Appraisal of Climate-Glacier Inter-linkages
}

B R ARORA and RESOURCE TEAM**

Member, National INSA-IUGG Committee, Former Director, Wadia Institute of Himalayan Geology, 36, Janakpuri, Engineer's Enclave Phase III, Dehradun 248001

**Resource Team: A P Dimri ${ }^{1}, D P$ Dobhal $^{2}, N C$ Pant $^{3}$, Milap Sharma $^{4}$, Paramanand Sharma ${ }^{5}$, Satyaprakash Shukla ${ }^{6}$ A L Ramanathan ${ }^{7}$ and Meloth Thamban ${ }^{5}$

${ }^{1}$ School of Environmental Sciences, Jawaharlal Nehru University, New Delhi 110 067, India

${ }^{2}$ Wadia Institute of Himalayan Geology, 33, G. M. S. Road, Dehradun 248 001, India

${ }^{3}$ Department of Geology, Delhi University, Delhi, India

${ }^{4}$ Centre for the Study of Regional Development, Jawaharlal Nehru University, New Delhi 110 067, India

${ }^{5}$ ESSO - National Centre for Polar and Ocean Research, Headland Sada, Vasco da Gama, Goa 403 804 , India

${ }^{6}$ Polar Science Division, Geological Survey of India, Faridabad, India

${ }^{7}$ Glaciology Lab, SES, Jawaharlal Nehru University, New Delhi 110 067, India

(Received on 21 March 2018; Accepted on 15 September 2018)

\begin{abstract}
The present review takes stock of the growth of crysospheric research in India with reference to glaciers and snow in the Himalaya, which are sensitive marker of the climate change. Overview of the snout and mass balance data indicates accentuated rate of glacier recession during the 1970's and 1980's, particularly in the Central and NE Himalaya. Like elsewhere on the globe, the retreating trends are consistent with the hypothesis of the global warming resulting from the increasing anthropogenic emissions of Green Houses Gasses. In contrast, the Glaciers in the Karakoram region, Indus basin, fed by mid-latitude westerlies, show marginal advancement and/or near stagnation. The climatic influence of temperature and precipitation (monsoon-vis-a-vis-westerlies) combine in complex manner to produce heterogeneous spatial or temporal variations in glaciers, including the slow-down in glacier retreat since 1990's all along the Himalayan arc. From continuously growing monitoring, it is apparent that beside the precipitation and temperature, geometry (wide and narrow), orientation (north or south phasing) of glacier, altitude distribution in accumulation/ablation zones, debris cover, lithology of rock types, process of erosion/weathering, atmospheric chemistry (black carbon) control the variability in glacier mass and hydrology. Quantification of various forcing parameters to allow their use in prediction of melt water contribution to perennial rivers is an important area of future research. Road map of future glacier-climate-hydrology studies, on the lines of ongoing studies in Antarctica-Arctic, is drawn with strong recommendations to establish National Institute of Glaciology.
\end{abstract}

Keywords: Cryosphere; Himalayan Glaciers; Climate-Glacier Linkages; Mass Balance; Snout; Hydrology; Arctic and Antarctic

\section{Background to the Glaciological Research in the Himalaya}

\section{Rationale and Perspective}

Extensive glaciers and snow that cover the elevated ranges of Hindu Kush-Karakoram-Himalaya together with contiguous Tibet (HKKH-T) represent the important constituents of the cryosphere (frozen

*Author for Correspondence: E-mail: arorabr47@gmail.com water). Since these glaciers and snow cover represent the largest store house of frozen water outside the polar regions, the HKKH-T region has been rightly named as Third Pole on the Earth (Dyhrenfurth, 1995; Qiu, 2008). Such extensive glacier/snow cover in contiguous belt creates its own microclimate and regulates the general climate of the area. In view of their occurrence in the ecologically sensitive high altitudes, they respond too readily to slight change in 
temperature and precipitation conditions, and, therefore, are recognized as a potential proxy for reconstructing the past and present climatic changes. It is now widely accepted that the Earth has witnessed several changes in climate especially during the last 1.6 million years that are exhibited by cyclic expansion and contraction of ice sheet and glaciers (Owen et al., 1998; Sharma and Chand, 2016). There are ample scientific observations to suggest that in the past century anthropogenic emissions of Green House Gasses are on the increase and are resulting in gradual enhancement in global mean temperature (IPCC, 2007; 2014). On the assumption that upward trend can have profound influence on the fragile glacial ecosystem by inducing accentuated melting, accelerated rates of recession of glaciers reported from various parts of the world are being attributed to the global warming caused by anthropogenic factors. Melt water released by the glaciers and seasonal snow serves are the perennial source of rivers originating from the Himalaya. These rivers are the life-line of the Indian landmass and several other South-Asian countries, such as Afghanistan, Bhutan, Bangladesh, Nepal, Pakistan, Myanmar. The melt water is source of energy for hydroelectric power plants, used for irrigation of agricultural lands in the command area especially during the summer period when it is most needed, and as well source of potable water for millions of people living in the mountainous and contiguous planes. The scientific study of Himalayan glaciers, therefore, assumes foremost importance for the management of water resources, hydro-power generation, climate/weather prediction and in sustaining the ecological system, particularly in the wake of growing population and compulsions of industrial and technological evolution. The probe into the impacts of climate change, especially due to anthropogenic factors, is high on the agenda of the Government of India. Prime Minister's Council on Climate Change has made the policy decision to create research capacity in knowledge institutions in the country. Dwelling on this subject at a brain storming session, coordinated by the Principal Scientific Advisor, a two-fold action plan was approved for implementation by the Department of Science \&Technology (DST). First, "A Study Group on Himalayan Glaciers" was constituted that gathered all the relevant data related to Himalayan glaciers and shared with all the stakeholder organization in the country (Patwardhan et al., 2010). Second, a proposal to establish a nodal Institute of Glaciology to undertake multi-disciplinary research on the Himalayan glaciers was agreed upon. In agreement with the proposed time bound program, a Centre for Glaciology at the Wadia Institute of Himalayan Geology (WIHG) was established in 2009, which shall eventually usher the establishment of a dedicated Institute of Glaciology. In the background of these rapid developments, we in this chapter first track in brief the illustrious history of the glaciological studies in the Himalaya allowing assessment of natural water reserve, degree and extent of climate changes on glaciers, melt water contribution to rivers etc. The pace and growth of glaciology research in the "Third Pole' region is well exemplified in the series of special publications, e.g. Patwardhan et al. (2010), DST (2012), Ravindra and Laluraj (2012), Pant et al. (2018), Goel et al. (2018) among many others. In the background of rich knowledge gleaned from the twentieth century initiatives, we discuss new initiative launched to have deep insight into the factors and physical processes controlling the effects of climate to show case the way forward of Indian glaciology research and its linkage with global research under the umbrella of International Association of Cryospheric Sciences.

\section{Growth Path and Participating Institutions}

Earliest information on Himalayan glaciers and snow can be tracked to the records available in the Gazetteers of the erstwhile States during the British. However, the seed of glacier research was sowed with the inception of Geological Survey of India (GSI) in 1851. Organized studies on secular movement of glacier were taken up starting since 1906 and several glaciers of Kuamon, Lahul and Kashmir region were monitored. Later, the studied were extended to encompass Sikkim and Karakoram Himalaya. After independence, during the 'International Geophysical Year (1957-58), 'International Hydrological Decade' (IHD: 1965-74) and later as part of the International Hydrological Programme (IHP) concerted efforts were made to systematize glaciological studies. Subsequently, a separate division on 'Snow, Ice and Glacier' was established by GSI in 1974, which was later rechristened as Glaciology Division. With this development, sustained field observational program on select glaciers expanded both in content and scope 
to include snout monitoring, mass balance studies, glacier dynamics, glacier-hydrology etc. In addition, meteorological monitoring was added to address issues related to climate-glacier linkage.

Himalayan Glaciological Programme sponsored by the Department of Science and Technology (DST), Government of India provided fresh thrusts and accelerated the pace of research in glaciology. The program launched in 1985 transformed the level of glacier research from field monitoring to specific theme based research. Under this program wide ranging projects aimed at on reconstruction of past climate, improving our understanding of forcing factors controlling the glacier dynamics, establishing its dependence upon climate, hydrology and environment has been carried out. In this DST program, Space Application Centre (SAC), Indian Space Research Organisation (ISRO) played pioneering role in implementing remote sensing as a powerful tool to monitor glacier dynamics by allowing mass balance and snout movement on large-scale and varied time resolution (Kulkarni, 1992). These studies provided major impetus to climate-glacier interactions. A major merit of the DST program was that it brought number of national research Institutions, e.g. Geological Survey of India (GSI) with its Division of Glaciology, Lucknow and Centre for Arctic and Antarctica Studies, Faridabad, Survey of India, (SOI), Dehradun, Wadia Institute of Himalayan Geology, (WIHG) Dehradun, Space Application Centre (SAC), Ahmadabad, Indian Institute of Remote Sensing (IIRS), Dehradun, Physical Research Institute (PRL), Ahmadabad, National Institute of Hydrology (NIH) Roorkee, India Meteorological Department (IMD), Birbal Sahni Institute of Palaeosciences (BSIP), Lucknow, GSI Sikkim, Central Water Commission (CWC), Jammu Division. Defense Terrain Research Laboratory (DTRL), New Delhi, and National Centre Medium Range Weather Forecasting (NCMRWF), New Delhi under the umbrella of cryosphere research. In addition, numbers of Universities, e.g. Delhi University (DU), Jawaharlal Nehru University (JNU), H. N. B. Garhwal University (HNBGU), Lucknow University (LU) and IITs etc are actively involved in glaciology research. National Center for Antarctica and Ocean Research (NCAOR), Goa, a unit of Ministry of Earth Sciences (MoES), is engaged with glaciology research in Polar Regions. The infrastructure and expertise developed are being used

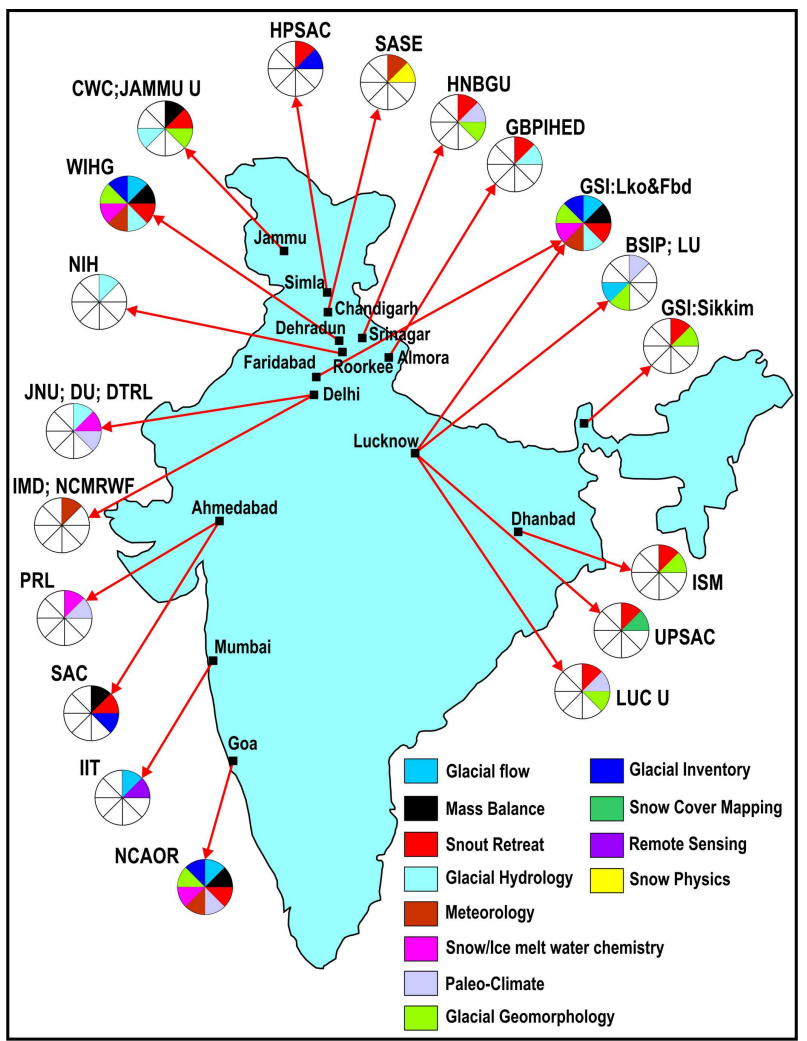

Fig. 1: Location of various organisations engaged in cryospheric research in India

to induct a more integrated approach to the Himalayan glacier studies. Here a multi-component research field station, named "HIMANSH" has been set up for monitoring glaciers of the Chandra basin, Western Himalaya. In addition, seasonal snow cover leading to snow avalanche and glacial lake outburst floods (GLOF) are major glacier related hazard, their monitoring and prediction are the primary subject matter of Snow and Avalanche Study Establishment (SASE), Chandigarh. Fig. 1 shows the geographical distribution of various research and academic organizations that has been engaged in study of frozen mass of water, i.e. glaciers, ice and snow in the Himalaya.

\section{Assessment of Glacier Resources: Inventory}

Glacier, ice and snow cover in the Himalaya are perennial source of rivers flowing out from Himalayas to the Indo-Gangetic Plains. To assess their water reserve for proper management and utilisation for agriculture, hydro-power generation etc; the inventory of glaciers, using the guidelines formulated by UNESCO (1970), became a priority theme of 
investigations. Based on these principles and use of different tools such as topographic maps, aerial photographs and satellite images of different scales and resolution formed the starting point to prepare inventory of Himalayan glaciers by a number of organizations. Incorporating Survey of India (SOI) topographic maps as reference, GSI prepared a preliminary inventory of glaciers incorporating Upper Indus, Chenab and Ravi, Ganga and Sutlej basins, which is included in World Glacier Inventory Status 1988 (IAHS-(ICSI)-UNEP-UNESCO, 1989). As noted, inventory compilations were initiated on basin levels, named by the central river. Integrating with the River Systems map published in the National Atlas of India, first edition of 'Inventory of the Himalayan Glaciers' was published by GSI (Kaul and Puri, 1999), which has been upgraded periodically. As per the last publication released in 2009, there are 9575 glaciers in Indian part of Himalaya. Basin wise distribution is given in Table 1. In short, about $17 \%$ of the Indian Himalaya area is covered with glaciers and additional area of nearly $30-40 \%$ supports the snow cover (Sangewar and Shukla, 2009).

Glacier inventory for the entire Himalaya has also been prepared by SAC with the help of satellite data. Beginning with the compilation of Kulkarni (1992) who using imageries on 1:250,000 scale reported total of 1702 glaciers covering an area of 23,300 sq km in Indian Himalaya. Since then glacier inventory using satellite data on 1:50000 scale has been upgraded for the entire Indian Himalaya (Sharma et al., 2008, Ajai et al. 2011; Bahaguna et al., 2014). More recent updated inventory shows strikingly large numbers of 32392 glaciers, occupying a total area of $71182 \mathrm{sq} \mathrm{km}$ (Ajai, 2018 and references there in). The total number and area covered differed greatly from that estimated by the GSI. Determination of precise numbers is uncertain due to terrain and observational difficulties. However, a part differences in the numbers, listed in Table 1, may due to the total area covered in respective exercises. The GSI inventory is confined to the geographical limits of Indian Himalaya whereas the satellite based inventory considers entire contiguous area of the Himalayan mountain belt, invariably trans-passing national boundaries. In addition, fragmentation of large extensive glaciers in to number of smaller glaciers could be major source of ambiguity in determining the precise number of glaciers. Further, use of remote
Table 1: Basin level distribution of Glacier resources of the Himalaya based on ground verified and satellite data

\begin{tabular}{|c|c|c|c|}
\hline \multirow[t]{2}{*}{ Sub-Basin } & \multirow[t]{2}{*}{ No. of glaciers } & \multicolumn{2}{|c|}{ Total No. of glaciers } \\
\hline & & GSI & ISRO \\
\hline \multicolumn{4}{|c|}{ Western Himalaya (Indus Basin) } \\
\hline Ravi & 172 & & \\
\hline Chenab & 1278 & & \\
\hline Jhelum & 133 & & \\
\hline Beas & 277 & & \\
\hline Satluj & 926 & & \\
\hline Indus & 1796 & & \\
\hline Shyok & 2658 & & \\
\hline Kishanganga & 222 & & \\
\hline Gilgit & 535 & & \\
\hline Sub Total & & 7997 & 16049 \\
\hline \multicolumn{4}{|c|}{ Central Himalaya (Ganga Basin) } \\
\hline Yamuna & 52 & & \\
\hline Bhagirathi & 238 & & \\
\hline Alaknanda & 407 & & \\
\hline Ghaghra & 271 & & \\
\hline Sub Total & & 994 & 6237 \\
\hline \multicolumn{4}{|c|}{ NE Himalaya (Brahmaputra Basin) } \\
\hline Tista & 449 & & \\
\hline Subansiri & No data & & \\
\hline Arunachal Part & 161 & & \\
\hline Sub Total & & 881 & 10106 \\
\hline Grand Total & & 9575 & 32393 \\
\hline
\end{tabular}

sensing from different season could leads to poor demarcation of glacier boundaries due to fresh snow fall on higher reaches. Validation of different formulations, based on remote sensing vis-à-vis topographic-cum-field investigations over a common basin/sub basin would be helpful to resolve the source of ambiguity and would pave way to prepare more authentic inventory. Despite large differentness in the total count of glaciers, based on the use of remote sensing or field investigations, two distinctive features which emerge are:

(i) Strike-along variation in the concentration of glaciers along the Himalayan arc are apparent in Table 1 when numbers are clubbed for three mega basins, namely the Indus basin, Upper 
Ganga basin and the Brahmaputra basins, representing respectively Western, Central and Eastern Indian Himalayan Region (IHR). The concentration is highest in Indus, followed respectively by the Brahmaputra and the Ganga basins. Similar longitudinal variations are also evident in the satellite derived glacier inventory (cf Ajai, 2018). The Indus basin has 16049 glaciers having glaciated area of $32246.43 \mathrm{sq}$ $\mathrm{km}$. The Ganga basin has 6237 glaciers occupying $18392.90 \mathrm{sq} \mathrm{km}$ of glaciated area. The Brahmaputra basin has 10106 glaciers occupying $20542.75 \mathrm{sq} \mathrm{km}$ of glaciated area.

(ii) Most of the glaciers are situated on the Main Himalayan Range, but other ranges, such as the Pir Panjal, Dhauldhar and Ladakh ranges also support glaciers. There are areas of concentration of high mountains along with the Himalaya and, consequently, they have greater concentration of Glaciers. Some of these areas are the areas of Nanga Parbat, Lolohai, Nunkun, Dibibokri-Chowkhamba-Nanda Devi, Dhaulagiri-Annapurna-Manaslu, Everest Makalu etc.

\section{Glacier Dynamics and Inter-linkages with Climate}

Glacier is a dynamic system that flows forward or has flowed at some time in the past under the influence of gravity, controlled largely by the basement bedrock topography. As it begins to move down the valley, its front making a giant wall of ice is called the snout and generally leis close to the lowest altitude of the glacier. The moving ice (glaciers) is a major erosional agent which sculptures the valley along which it moves and in the process deposits thick pile of assorted sediments. On the assumption that erosion rates respond sensitively to the climate change, geochemistry of the sediments coupled with powerful radiometric dating techniques is used to reconstruct the past climate which can be cross checked with other independent climate sensitive proxies like tree rings and pollen records from lakes and peat logs. Furthermore, the isotopic composition of trapped gases and trace metals in ice layers could be measured. Based on these proxies, it is now possible to reconstruct the climatic fluctuations spanning over several centuries to several millennia. These studies are now routinely carried out under the heading of "Quaternary Climate Change".

\section{Quaternary Climate Changes}

Applications of long term proxies has shown that the Earth has witnessed several pronounced oscillations in global climate especially during the last 1.6 million years (Quaternary) that are exhibited in the expansion and contraction of ice sheets and glaciers in Polar Region. These climatic fluctuations have followed a series of distinctive pattern which occurred at regular frequency and are attributed to the changes in solar influx caused due to the sun-earth geometry (orbital forcing). The orbital driven long-term cycles of 100 ka (eccentricity), $41 \mathrm{ka}$ (obliquity) and $21 \mathrm{ka}$ (precession of equinoxes) were superimposed by abrupt climatic events of decadal, centennial and millennial scale and are well represented in the icecore (GRIP members, 1993), marine (Schulz et al., 1998) and continental records (Gasse et al., 1990), which can be estimated using the isotopic ratios. Longterm climate model so constructed will not only help in identifying the contributory role of various forcing factors but also serve as benchmark against which predictive models of future climate can be evaluated. Such reconstruction studies have shown that most recent period of glaciations is attributed to the Little Ice Age (LIA) that probably terminated during the mid- $19^{\text {th }}$ century. Following this, the current phase of warm period is believed to be continuing.

In comparison to polar ice caps, attempts to reconstruct climate records for the geological and historical periods for the Himalayan glaciers using chronometric, stable isotope ratios, geomorphological markers or biotic proxies have begun to appear only recently. Initial studies particularly from the western and central Himalayas suggested that glaciers have fluctuated in response to the Quaternary climate change. The limited chronometric data provides a broad picture of major glaciations occurring around $\sim 70 \mathrm{ka}-30 \mathrm{ka}, \sim 17-10 \mathrm{ka}$, and $<5$ to $4.5 \mathrm{ka}$ (Sharma and Owen, 1996; Owen et al., 2001; Nainwal et al., 2007). In addition, based on morphology and relative dating technique, a marginal but regional glacier advance was observed during the Little Ice Age (Sharma and Owen, 1996; Mazari et al., 1996; Nainwal et al., 2007). For example, in Lahul-Spiti region, a phase of recession was followed by 
advancement during the Medieval Warming period and Little Ice Age (LIA) respectively (Mazari et al., 1996). In another study, Chauhan (2006) observed phase of glacier recession, caused due to moist climate during 1300 to $750 \mathrm{yrs} \mathrm{BP}$, was followed by readvancement after 450 years BP due to cold climate. High-resolution pollen and diatom proxies from a peat deposit in the Pindar valley of Higher Central Himalaya indicated prevalence of wetter condition during the last two centuries that exceeded changes recorded over the last three millennia (Rühland et al., 2006). Recent tree ring data from Bhagirathi valley have been used to reconstruct high resolution spring precipitation changes since 1731 AD (Singh and Yadav, 2005). During this period, the data suggests highest precipitation during 1977-1986, whereas, lowest precipitation was observed during 1932-1941. Understanding of the Quaternary climatic fluctuations is still evolving (Sharma and Chand, 2016). The crossvalidation of such proxies remain an open issue as AWS or meteorological observations in high altitude areas of Himalaya, to record wet precipitation, are still (nearly) not existing. The study of the tree is confined to altitudes below the snow line where trees mark their presence. However, as already pointed higher temperature would result in reduced accumulation of snow and lead to increased wet precipitation that causes mass wasting of glaciers at low altitudes.

\section{Inter-Annual and Inter-Decadal Climate Changes}

Glaciers in the ecologically sensitive high altitudes, respond too readily to slight change in temperature and precipitation condition, and, therefore, are projected as a potential proxy for reconstructing the present and immediate past climatic changes. From the current trends in temperature changes, it has been inferred that the mean global surface temperature has risen by $0.85 \pm 0.2^{\circ} \mathrm{C}$ from 1880 to 2012 (IPCC, 2014). Further, there are arguments to suggest that the climate change marked by global temperature increment of even less than one degree Celsius can have profound effect on the fragile glacial and periglacial ecosystem. Noting that increasing global temperature is marked by source level increase in the anthropogenic emission of carbon dioxide in atmosphere as well as by the rising of mean sea levels, wide ranging claims are made to attribute the accentuated recession of glaciers in various parts of the world to the global warming induced by anthropogenic factors. Such extensive glacier/snow cover in contiguous belt creates its own microclimate and regulates the general climate of the area. The observable changes in the onset and durations of seasons, precipitation pattern manifested in water shortages, variability in the biodiversity in some way or other are considered the pointer of changing climate by increasing anthropogenic effects. Adaptability of glaciers to climate change is a topic that is catching global interest with a focus to devise strategies of combating impacts of the change. Direct field observation in the form of snout monitoring and mass balance studies have been in use for deciphering the inter-annual and inter-decadal scale climateinduced changes in glaciers. Isotopic ratios can also provide extremely valuable information on the temporal changes in the atmospheric chemistry, especially the concentrations of certain anthropogenic substances in the atmosphere and, thus, help in understanding the anthropogenic loading particularly after the post-industrial era.

\section{Snout Movement: Proxy to Climate Variability}

The rising temperature in the lower periphery (altitude) of the glacier results in higher melting in the ablation zone (due to hot air influx), seen as the retreat of snout. Similarly, if the temperature falls, the snout of glaciers will advance. Hence the monitoring of the snout position, being function of the length and area of the glacier, emerged as pioneering proxy to the changing climate. It received wide acceptance as the World Glacier Monitoring Service (WGMS, 1989) began reporting every five years the changes in the snout position of glaciers from around the world.

Systematic snout monitoring in the Himalaya were initiated by GSI (Vohra, 1981; Raina and Srivastava, 2008). Gangotri glacier has been monitored since 1935. The snout of Gangotri glacier has been receding at least for the last 75 years. The total retreat from 1935-96 is about $1400 \mathrm{~m}$ at the average rate of retreat since 1956 is $\sim 31 \mathrm{~m} / \mathrm{yr}$ (DST, 2012). There was acceleration in the retreat in the mid-seventies and eighties with a marginal slowing down in the nineties. According to Raina (2009), the glacier has almost remained static from 2007-09. Some 50 other glaciers have been brought under the ambit of snout monitoring program of the GSI since the late nineteenth century. Apart from it, snout monitoring at couple of glacier, Chota Shingri, Dokraini and Chaurabari were 
intiated by WIHG. Fig. 2 depicts the retreat pattern of some of the important glaciers, averaged over different time periods (Vohra, 1981; Raina and Srivastava, 2008). The rates of retreat vary between $5-30 \mathrm{~m} / \mathrm{yr}$ for different glaciers with different geometries and located in different climatological set ups. Majority of the glaciers in the Central and the Eastern Himalaya are retreating (melting) wherein the rate of retreat increased many folds during midseventies to late-eighties, touching avalue of $25 \mathrm{~m}-30 \mathrm{~m} /$ year, e.g. the Gangotri glacier. Thereafter, the rate of retreat has slowed down during the last decade of the $20^{\text {th }}$ century or at the start of $21^{\text {st }}$ century (Raina, 2009).

\section{Mass Balance: Proxy to Climate Variability}

Mass balance of a glacier is measure of total loss or gain in glacier mass at the end of hydrological year (Paterson, 1994). This is estimated by measuring total accumulation of seasonal snow and ablation of snow and ice over a year, starting from some fixed date, generally $30^{\text {th }}$ September, close to the end of the ablation. In the widely used conventional glaciological method for mass balance, the assessment of winter accumulation is achieved by pitting whereas ablation is by way of stake network over a glacier. Changes in glacier mass balance are considered as the most sensitive indicator of climate change. The annual mass balance studies based on the fixed date system were initiated by GSI in the year 1974 at Gara Glacier, J \& K (Raina et al., 1977). The network of mass balance studies were further spread by GSI and other research organizations like WIHG and academic groups from JNU and Jammu University under the DST integrated program. Taking stock of mass balance studies, it has been recorded in DST (2012) that in between 19742012 only 13 glaciers, representing the varying climatic conditions, were studied with the time span of measurements ranging in length from 2 years to 10 years. The studies have indicated overall negative glacier mass balance during the latter part of $20^{\text {th }}$ century as well as in early $21^{\text {st }}$ century (Gaddam et al., 2016, 2017a; Dobhal et al., 2008, 2013, Pratap et al., 2015; Brun et al., 2015). Given that the majority of the glaciers of Himalaya are in state of instability, it has been envisaged that their volume may significantly reduce if the climate stabilizes at its present state (Gaddam et al., 2016, 2017a). At present, in-situ mass balance studies are continuing on a few select glaciers, namely, Dokriani and Chaurabari (by WIHG), Hamta (by GSI), Chhota Shigri (by JNU) and Chandra Basin (NCAOR and DU). Long term trend in mass balance at some of these individual stations are discussed later.

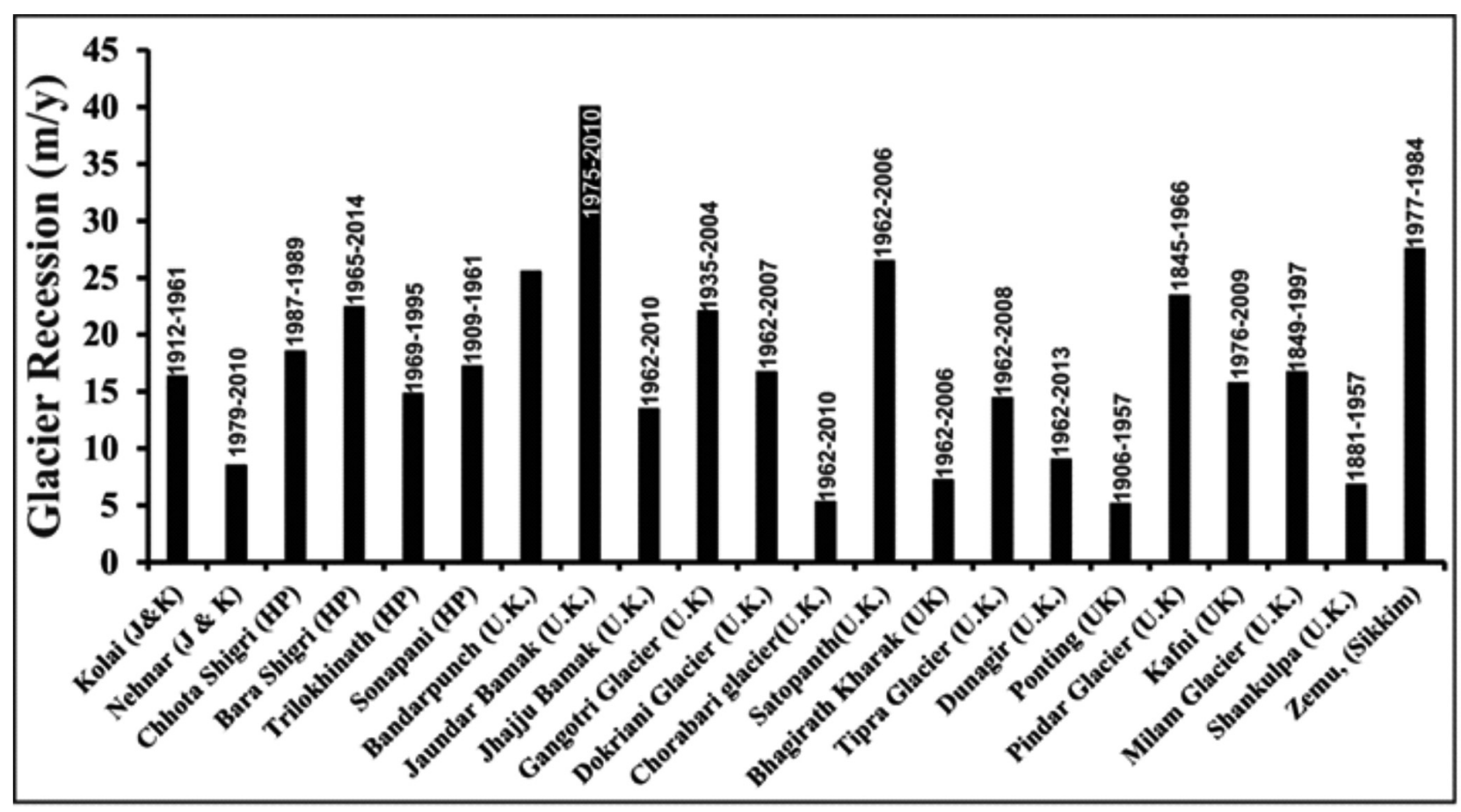

Fig. 2: Snout recession trend of Himalayan glaciers (Modified from Vohra, 1981) 
In addition to field based snout and mass balance monitoring, remote sensing data provides information on the areal extent of the glacier and snow cover. In order to obtain climate sensitive index of large number of glaciers, accumulation area ratio (AAR), defined as a ratio between accumulation area and total glacier area, has been widely used (Meier and Post, 1962). Accumulation area is an area of glacier above equilibrium line which coincides with snow line as in temperate glacier the extent of superimposed-ice zone is insignificant. To estimate glacial mass balance, a relationship between AAR and mass balance was developed using field mass balance data of the Shaune and the Gor Garang glaciers (Singh and Sangewar, 1989). The AAR and snout estimates using remote sensing data of different time scale and duration have been extensively used to study the health of glaciers all along the Himalayan arc (Bhambri et al., 2011; Kulkarni et al., 2011; Ajai et al., 2011; Sharma et al., 2013a; Bhauguna et al., 2014); Kulkarni et al. (2011) estimated the glacial retreat for 1868 glaciers spread over 11 river basins of Himalaya. It was found that for the period between 1962 and 2001/2002, the total glacier area reduced from 6332 to $5329 \mathrm{~km}^{2}$ - an overall de-glaciation of $16 \%$. Further, focusing on the changes in length and area of 82 glaciers in Bhagirathi and Alaknanda basins, Bhambri et al. (2011) indicated that glaciated area suffered net loss of $4.6 \%$ between 1968 and 2006. It follows that while examining the AAR data for the entire Himalaya as a single unit or individually for the Ganges and Brahmaputra River Basins, representing respectively the Central and NE Himalaya, there is overall reduction in the glaciated area over the prolonged period, mostly post-1962. A major exception to this decreasing trend is witnessed in the Karakoram region, Indusbasin. Here, observations point to advancement or slower rate of retreat of glaciers. For example, a study of 30 glaciers in the centeral Karakorm region during 1997-2001 conclusively showed advancement and/or thickening of tongue by 5-20 $\mathrm{m}$ and this heterogeneous behaviour was termed Karakoram anomaly by Hewitt (2005). It is widely recognised that SW and NE Indian monsoon is the dominant source of moisture for the major part of the Himalaya (Khan et al., 2018). The Karakoram lies far away from the influence of SW Indian monsoon and the mountain receives a major contribution of the snow through westerlies during the winter (Archer, 2001; Treydte et al., 2006).
Therefore, the depletion or growth of the Karakorm glaciers are more sensitive to weakening and strengthening of the westerlies.

\section{Identification of Forcing Factors Influencing Health of Glaciers}

Synthesis of mass balance and snout movement data indicates that glaciers in the Himalaya, over a period of the last 70-80 years, have responded in contrasting ways. However, the cumulative negative balance observed in large part of the Indian Himalaya is clear pointer that rise in temperature related to global warming is an important forcing factor controlling the health of the glacier. As against the retreating trend of glaciers in Central Himalaya, glaciers in the Karakoram region, Western Himalaya show advancement. It is suggested that the sources of precipitation nourishing the glaciers (monsoon-vis-avis westerlies and their contrasting seasonal characteristics) determine the contrasting movement of the glaciers in different basins. Long term ground monitoring of snout have also indicated that rate of glacier recessions in the Ganga basin, including Gangotri glacier, have reduced many folds from eighties to the end of the past century or during the early part of current century (Raina and Srivastava, 2008, Raina, 2009).The monitoring of snout from remote sensing data separately for the two periods of 1989-90 to 2001-04 and 2001-02 to 2010-11 corroborate the slowing down of glacier recession in recent years (Ajai, 2018). During the period of 198990 to 2001-2004, 76 per cent of the glaciers have shown retreat, 7 per cent have advanced and 17 per cent have shown no change. As compared to this during the next decade i.e. 2001-02 to 2010-11, only 12.3 per cent glaciers have shown retreat, 86.6 per cent of glaciers have shown stable front and 0.9 per cent have shown advancement. Analogous observation on the rate of glacier retreat are indicated by Ganjoo et al. (2014) from the extensive study of snout fluctuations in the Nubra valley, Indus Basin in Western Himalaya. Their study indicated that the glacier in the Nubra valley had vacated $56 \mathrm{~km}^{2}$ of the area between 1969 and 1989 and only $4 \mathrm{~km}^{2}$ between 1989 and 2001 suggesting the slowing down in the rate of glacier retreat since 1990. Forcing effects of temperature and precipitation perhaps combine in complex mode to produce contrasting spatial and temporal variability in glacier dynamics. Variations in 
the rate of snout-recession from one glacier to other in the same basin could be pointer that apart from the temperature-precipitation, other physical factors, debris cover, affect the glacier movements (Sharma et al., 2016a). There are also examples when snout recession of individual glaciers differ significantly from those inferred from mass balance studies in the same basin. This necessitates validation of climate induced change deduced from one proxy with other, preferably from the same glacier to derive correct interpretation of cause-effect relation. As a prat of DST integrated program on Himalayan glacier, number of multidisciplinary studies were undertaken by increased participation of institutes with varying expertise. Below, we discuss the results emanating from couple of such integrated studies, which help to identify various forcing factors influencing the dynamics of the glaciers.

\section{Case study of Dokriani and Chorabari Glaciers, Central Himalaya: WIHG}

\section{Mass Balance and Snout Variability: Control of Area-altitude Distribution}

WIHG has been engaged in monitoring Dokriani ( 7 $\mathrm{km}^{2}$ ) Glacier in Bhagirathi basin and Chorabari $\left(6.4 \mathrm{~km}^{2}\right)$ glacier in the Alaknanda basin for mass balance and snout movement studies over the last one and half decades (Dobhal et al., 2008; 2013). Both glaciers exhibit retreating snout as well as negative mass balance trend (Dobhal et al., 2013). Curiously, while the snout at Dokriani glacier retreated with average rate of $18.5 \mathrm{~m} / \mathrm{yr}$, the Chorabari glacier receded at just half of the Dokriani rate, i.e. $9.5 \mathrm{~m} / \mathrm{yr}$. In contrast to this, Mass balance figures showed reversed trend i.e. for Chorabari glacier loss of mass at the rate of $0.77 \mathrm{~m}$ w.e. $\mathrm{a}^{-1}$ (ELA, $5060 \mathrm{~m}$ ) is almost double compared to the Dokriani Glacier i.e. $0.45 \mathrm{~m}$ w.e. $\mathrm{a}^{-1}$ (ELA $5040 \mathrm{~m}$ ) during the same study period (Fig. 3). The study apparently suggests that even if a glacier snout has stable fronts (no retreat) for the certain periods, it does not essentially imply that the glacier is not melting or growing.

Critical appraisal of geometrical parameters of the Dokriani and Chorabari glaciers bring home that area-altitude distribution of accumulation and ablation zone in relation to the snowline or equilibrium line altitude (ELA) control the rate of glacier recession/ mass balance. For example, the Dokriani glacier has

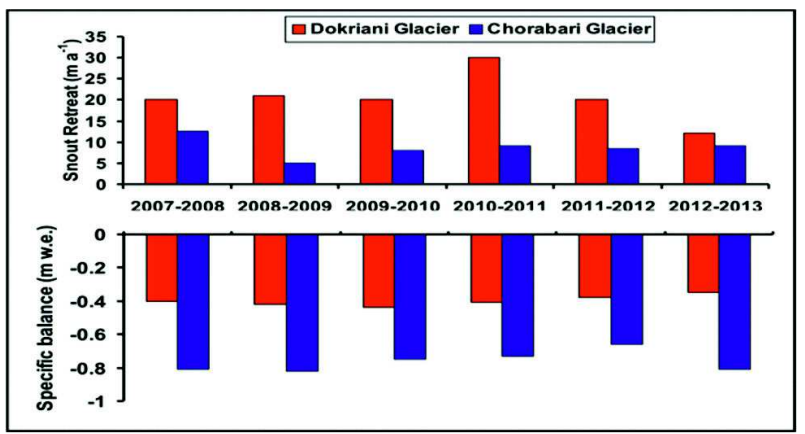

Fig. 3: Variability between mass balance and snout retreat of Dokriani and Chorabari glacier, Central Himalaya

almost $68 \%$ area above ELA/snow line altitude and Chorabari has smaller accumulation area (43\%). In the case, the glacier has a large accumulation area above the ELA, then the glacier will experience positive or comparatively low negative mass balance. Conversely, the glacier with large ablation area will impart surface melting at faster rate.

\section{Case Study of Chandra Basin, Western Himalaya: NCAOR and JNU}

\section{Mass Balance: Influence of Debris Cover}

All the glaciers under observation in the Chandra basin in Western Himalaya during the last 4-5 years have shown cumulative negative mass balance (Sharma et al., 2016a; Patel et al., 2016), which in terms of retreat are similar to other glaciers elsewhere in the Himalaya, except Karakoram region (e.g. see Section 2.2.2 and references therein). A significant mass wastage was also observed in Baspa basin, Western Himalaya, during last decades and this loss is strongly supported an increasing trend in annual mean temperature and decreasing trend in precipitation (Gaddam et al., 2016, 2017a).

The mean vertical mass balance gradient of Western Himalaya during last two years is similar to Alps (Sharma et al, 2016a), as well as the Nepal Himalaya (Mandal et al., 2014; Azam et al., 2012). Mass balance is found to be dependent on solar radiation, debris cover, local and regional precipitation, slope and the shading effect of surrounding steep slopes (Sharma et al., 2016a; Patel et al., 2016). Similar observations were made by some other researchers working on Himalayan glaciers (Azam et al., 2016; Venkatesh et al., 2012). Winter 
precipitation and summer temperature are almost equally important for controlling the mass waste pattern of Western Himalayan glaciers at decadal scale (Azam et al., 2014; Thayyen et al., 2010). Debris cover is one of the significant controlling factors for spatial variability of ablation rate. In contrast to the normal ablation pattern, debris covered glaciers experienced an inverse ablation rate with altitude. Thicker debris protect ice surface efficiently from melting than thin debris (Sharma et al., 2016a,b; Patel et al., 2016).

\section{Melt Water Contribution to Stream Flows: Seasonal Control}

An increasing trend is observed in snow cover in all seasons, except spring, during the last decade which is in variance to earlier deduction that decrease in perennial snow cover area leads to significant decrease in stream flows (Ahluwalia et al., 2015; Joshi et al., 2015). Irrespective of latitudinal differences, glacier melt contributes up to $\sim 16 \%$ of the total discharge in Himalayan glacial basins. Maximum discharge takes place from mid-July to mid-August (Ahluwalia et al., 2015; Joshi et al., 2015; Thayyen et al., 2010) thereafter discharge diminishes drastically from mid of September(Sharma et al., 2013b). Runoff contribution from snow melt ( $81 \%)$ seems to be more than from rainfall $(11 \%)$ and ice melt $(8 \%)$ during 2000 to 2014 in the Baspa basin, western Himalaya (Gaddam et al., 2017b). In Indus basin, glacier melt contributes up to $\sim 44 \%$ of the total discharge; however, for Chandra basin it is little higher (Singh et al., 2017).

\section{Hydrochemistry of Melt Water: Sources of Suspended Sediments}

Hydrochemistry of melt water in Chandra basin is dominated by $\mathrm{Ca}^{+2}$ and $\mathrm{HCO}_{3}$ and shows three dominant composites i.e., the water-rock interaction, atmospheric dust inputs and physico-chemical changes. High molar $\mathrm{Ca}^{2+} / \mathrm{Na}^{+}, \mathrm{Mg}^{2+} / \mathrm{Na}^{+}$and C-ratio indicate that weathering of disseminated carbonates contributes more than silicate weathering to the chemical composition in Chandra basin, Western Himalaya (Singh et al., 2017). Mean solute load is only $10-15 \%$ of the mean sediment load reflecting solute released from sediment in transit is extremely lower than in proportional of solute derived from subglacial channels and ice rock interface (Singh et al., 2017).

\section{Case Study of Chhota Shigri, Lahaul-Spiti Valley: JNU and DU Component}

The Chhota Shigri glacier, located in Lahaul and Spiti valley, was selected as a representative glacier in Western Himalaya for the joint expedition lead by WIHG, under a DST program (1986-1989). Since 2002 , it has been monitored for the long term annual mass studies. Over the years, Glaciology Laboratory, JNU has added many more field glaciological tools to measure energy balance, hydrology, Hydrogeochemistry, isotope, remote sensing, modelling studies etc.

\section{Mass and Energy Balance: Seasonal Control}

Fig. 4 provides the long-term seasonal and annual mass balance series of Chhota Shigri glacier. Over last 13 years, 2002-2015, the Chhota Shigri glacier has lost mass with a cumulative glaciological mass balance of $-6.88 \mathrm{~m}$ w.e. (water equivalent), corresponding to a mean annual glacier-wide mass balance of $-0.53 \mathrm{~m}$ w.e. $\mathrm{a}^{-1}$ (Azam et al., 2016; Mandal et al., 2014). However, for short intervals, i.e. 2004-05, 2008-2011, the glacier experienced positive mass balances. The highest negative melting throughout the entire measurement period (since 2002), with a cumulative value of $\sim 50 \mathrm{~m}$ w.e., is observed in the lower ablation part close to $4425 \mathrm{~m}$ a.s.l. (excluding debris-covered area). Over the debris covered part, melting at the lowest part of the ablation zone is reduced by -1 to $-2 \mathrm{~m}$ w.e. $\mathrm{a}^{-1}$ regardless of its altitude. This is attributed to the "debris effect" that protects the ice beneath the debris-cover from direct solar radiation and surface atmosphere (Mandal et al., 2014). The studies also found that the summer snowfall on Chhota Shigri glacier has a significant impact on the annual mass balance. If a significant snowfall happens during summer, it reduces the surface melt by increasing albedo of glacier surface resulting in a significant amount of melt reduction and ultimately annual mass balance is towards positive or slightly negative in the particular years, e.g. 2010 and 2011 (Azam et al., 2014). 


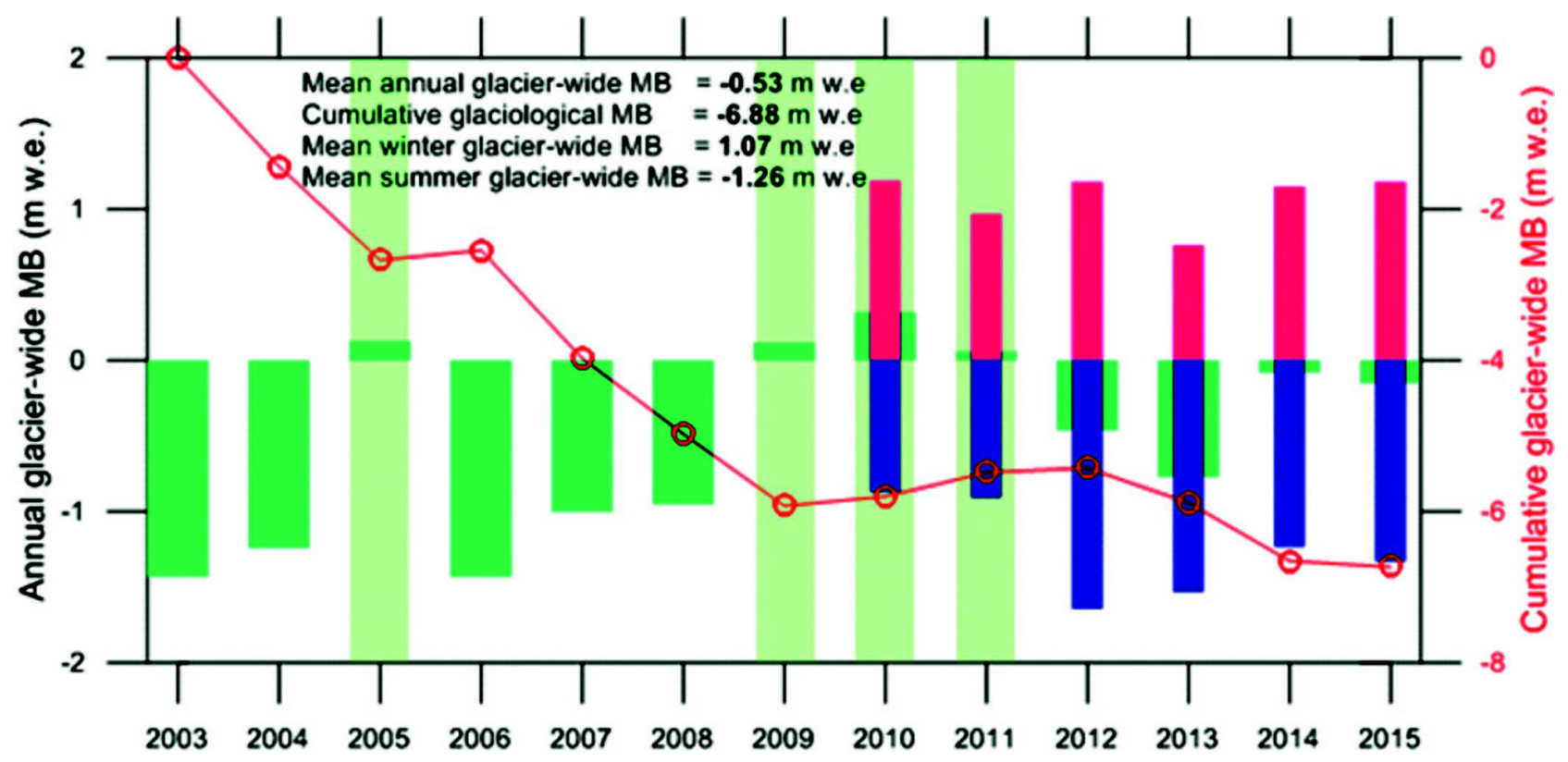

Fig. 4: The annual (green histograms) and cumulative (line with red circles) glacier-wide MBs of Chhota Shigri glacier between 2002 and 2015. Light greed shads are the years with positive (+) glacier MB. Also shown are the seasonal (winter (purplish-red histograms) and summer (deep blue histograms)) glacier-wide MBs between 2009/10 and 2014/15 hydrological year. The figure is adopted from Mandal (2016)

Glacial Hydrology, Hydrochemistry: Discharge Rates and Sediment Mass

JNU Glacier Research Group included hydrology and hydrochemistry in their study plan and also expanded activities on various Central and Western Himalayan glaciers such as Chhota Shigri, Patsio, Gangotri, Bara Shigri, Batal glaciers etc. Velocity area method was used for discharge measurement. Ion Chromatograph and standard analytical methods (APHA 2005) were used for the hydrogeochemical study.Temporal variations in the concentrations of major cations, major anions, TDS and discharge are shown in Fig. 5A-C (Singh and Ramanathan, 2017). Distribution of melt water runoff from the Chhota Shigri glacier shows increasing trend from June onward and attains to its maximum value in July and August and after that, it starts declining. Based on the daily mean daytime and night time discharge, study shows strong storage characteristics of melt water during the early part of ablation period, which reduces with the progress of melt season. Diurnal variations in discharge show that minimum runoff occurred in the morning $(0700-0900 \mathrm{~h})$ and maximum runoff occurred in the afternoon and evening (1500-1800h). The time lag between melt water generation over the surface of Chhota Shigri glacier and its emergence as runoff is higher in the early ablation period as compared to the peak ablation period. A strong relationship was observed between suspended sediment concentration and the discharge of Chhota Shigri, Patsio and Batal glaciers. In addition, the hydrological variation of melt water is mainly controlled by the temperature of the study area. The investigations also indicate that suspended sediment concentration in the melt water of Gangotri and Bara Shigri glaciers are higher than the Chhota Shigri glacier. Such type of results may be due to high melt water runoff, more availability of rock debris and large size of these glaciers as compared to the Chhota Shigri glacier. The sediment yield from the catchment of Chhota Shigri glacier was lower as compared to the Gangotri glacier, which may be due to low glacial runoff, lithology and lower physical weathering rates in the Chhota Shigri glacier (Engelhardt et al., 2017; Singh et al., 2016; Singh and Ramanathan, 2017).

Melt water draining from Chhota Shigri, Bara Shigri, Gangotri and Batal glaciers is slightly acidic in nature, whereas melt water of Patsio glacier is nearly neutral in nature. Bicarbonate is the dominant anion in the melt water of Chhota Shigri, Bara Shigri and Patsio glaciers, whereas Sulphate is the dominant anion 

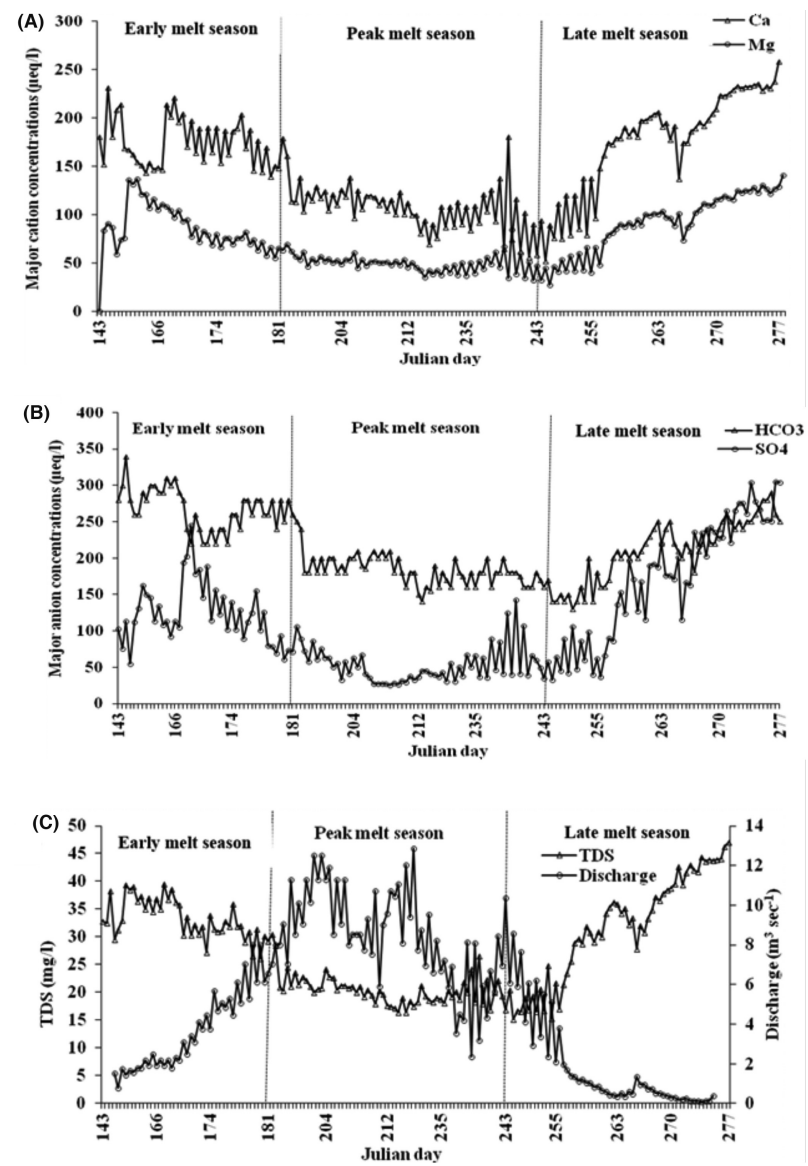

Fig. 5: Temporal variations in the major ion concentration with discharge in Chhota Shigri Glacier (Adopted from Singh and Ramanathan, 2017)

in the melt water of Gangotri, Chaturangi and Batal glaciers. Calcium is the dominant cation in all studied Central and Western Himalayan glaciers. High contribution of $(\mathrm{Ca}+\mathrm{Mg})$ vs the total cation and high equivalent ratios of $(\mathrm{Ca}+\mathrm{Mg})$ vs $(\mathrm{Na}+\mathrm{K})$ for the studied Himalayan glaciers melt water show that hydro-geochemistry of these studied glaciers was mainly controlled by carbonate weathering followed by silicate weathering. The average ratio of $\mathrm{Na} / \mathrm{Cl}$ and $\mathrm{K} / \mathrm{Cl}$ in the melt water of Chhota Shigri, Bara Shigri, Patsio, Chaturangi, Gangotri and Batal glaciers melt water was much higher than the sea aerosols, showing the low atmospheric contribution of these ions to the total solute budget of these glaciers. A trace amount of $\mathrm{NO}^{3}$ and $\mathrm{PO}^{4}$ was reported from the Central and Western Himalayan glaciers melt water, showing palatability of melt water. Seasonal variations in the TDS concentration of melt water was inversely correlated with discharge, which means their concentration was minimum during the peak melt period (July and August) and maximum during the end of ablation period (September and October) in the Chhota Shigri glacier. Dissolved load, cation and chemical weathering rates and associated $\mathrm{CO}_{2}$ consumption rate due to silicate, carbonate and chemical weathering are higher during the peak melt period because of more runoff and lower during the late melt period due to low discharge from the Chhota Shigri glacier. The annual $\mathrm{CO}_{2}$ drawn down by the Chhota Shigri glacier is much lower than the Gangotri glacier, which may be due to low discharge and smaller basin area as compared to the Gangotri glacier (Sharma et al., 2013b; Singh et al, 2016; Singh and Ramanathan, 2015).

\section{Forcing Effects in Average Annual Precipitation: DU}

Among all the hydro-meteorological parameters, precipitation (snowfall and rainfall) is the most difficult to predict due to its inherent variability in time and space (Guenni and Hutchinson, 1998), particularly for a complex mountainous terrain like Himalaya. Poor network of in situ rain gauges particularly in mountainous region, inaccessible terrain, high altitude variation and significantly large size of basins forces adaption of remote sensed based (TRMM-342) estimation of average annual precipitation. Recently, Khan et al. (2018) investigated precipitation patterns for the Indus, the Ganga and the Brahmaputra basins by using satellite based Tropical Rainfall Measuring Mission (TRMM-3B42) data and validated it with APHRODITE and IMD interpolated gridded precipitation data (Fig. 6). The entire basin areas within the geographic limits of India were considered. Derived from a ten-year TRMM-3B42 data set, the average annual precipitation for the Indus, the Ganga and the Brahmaputra basins is estimated as $413 \mathrm{~mm}$, $1081 \mathrm{~mm}$ and $1460 \mathrm{~mm}$ respectively. Validation of TRMM-3B42 data with the rain gauge IMD data correlates well particularly for the Ganga basin as unlike Indus and Brahmaputra basins, more than $80 \%$ part of the Ganga basin lies within the Geographical boundary of India (Khan et al., 2018). Consideration of data not covering the entire basins is inferred as the cause of high variability for the other studied basins. Reported precipitation variability for the Indus basin is more than $250 \%$, for the Ganga basin it is $100 \%$ and for the Brahmaputra basin it is more than 


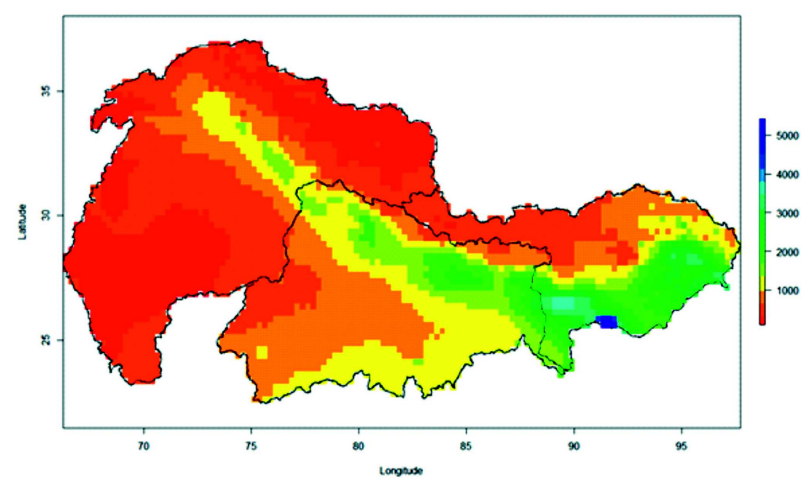

Fig. 6: Ten years (2001-2010) average annual precipitation map of the Indus, the Ganga and the Brahmaputra basins derived from TRMM-3B42 (From Khan et al., 2018)

240\% (Immerzeel et al., 2010; Jain and Kumar, 2012). Khan et al. (2018) further showed that the precipitation broadly follows an east-west and northsouth gradient control, i.e. the eastern most Brahmaputra basin has the highest amount of precipitation followed by Ganga and western most Indus basin has least precipitation. The precipitation is highest on the higher elevation than at lower elevations of the basins. The contoured distribution of precipitation indicates the orographic control as the primary factor on the summer monsoon precipitation in the Ganges and the Brahmaputra basins. Indus basin behaves independent of the Indian summer monsoon.

Estimation of Glacial Melt Fraction: DU, NIH and GSI

Bhagirathi and Alaknanda basins in the upper Ganga valley have been studied for estimation of glacial melt fraction. The Gangotri glacier which constitutes nearly a fifth of the glacierized area of the Bhagirathi basin represents one of the fastest receding, large valley glaciers in the region which has been surveyed and monitored for over sixty years. Availability of measurements over a long period and relatively small glacier-fed basin for the Bhagirathi River provides suitable constraints for the measurement of the glacial melt fraction in a Himalayan river. Calculations of existing glacial melt fraction $\sim 30 \%$ at Rishikesh (Maurya et al., 2011) are not consistent with the reported glacial thinning rates (Dong et al., 2013). It is contended that the choice of unsuitable endmembers in the three component mixing model causes the overestimation of glacial melt component in the river discharge.
Khan et al. (2017) applied three component mixing model by using oxygen isotope and electrical conductivity. The fundamental assumption is that the liquid (water) and solid (snow) precipitation will distinctly fractionate the light and heavy isotopes of oxygen. Since the precipitation of snow is altitude dependent, snow (and also ice) is likely to contain less amount of heavier $\left({ }^{18} \mathrm{O}\right)$ isotope compared to liquid precipitation. The oxygen isotope composition is expressed in the form of a ratio expressed as parts per thousand or parts per million (ppm) in reference to a standard composition. In the context of a Himalayan river it can be assumed that the river discharge comprises three components, namely (i) Surface runoff due to summer rainfall, post monsoon interflow and winter snow melt from the catchment area (R), (ii) Glacier ice melt (I), and (iii) Ground water $(\mathrm{G})$.

Pre- and post-monsoon samples reveal a decreasing trend of depletion of $\ddot{a}^{18} \mathrm{O}$ from upstream to downstream. By careful selection of end members, Khan et al. (2017) have estimated $\sim 12 \%$ glacial melt fraction in the Bhagirathi basin and $\sim 9 \%$ glacial melt fraction in the Alaknanda basin and at Rishikesh. Glacial melt fraction decreases from the upstream to downstream during the pre-monsoon and the postmonsoon period, whereas surface run off in the form of snow melt is the major fraction during the premonsoon and in the form of rainfall during the post monsoon period in the upper Ganga basin. Ground water contribution varies significantly from $39 \%$ during pre-monsoon to around $17 \%$ during post-monsoon in the Bhagirathi basin. Their estimated glacial melt fraction matches closely with the reported thinning rates of the Himalaya.

\section{Snow Cover Fraction: JNU, SAC}

Major Indian Rivers and their tributaries originating in the Himalayas depend upon seasonal snow cover melt during crucial summer months. In addition, accumulation and ablation of the seasonal snow cover are important parameters to assess snow-climate interactions, snow hazard prediction modeling (IPCC, 2007; Konz et al., 2010). Due to rugged and unapproachable terrain and harsh weather conditions in situ snow and ice observation is one of the limitations. This data gap has been bridged by usages of remote sensing with suitable image processing 
techniques (Arora et al., 2011; Brun et al., 2015). Though there are still inherent problems due to resolution and validation, but they can provide a benchmark detailing for the estimates (Hasson et al., 2014). Based on remote sensing techniques, snowcovered areas in the Himalaya/Tibet region is reported to have decreased by one-third at the rate of $\sim 1 \%$ $\mathrm{a}^{-1}$ during 1966-2001 (Rikiishi and Nakasato, 2006). During 1986-2000, the western Himalayan snowcover showed a synchronous decline with an increase in snow melt data from 1993 onwards (Kriplani et al., 2003). During 1990-2001 an annual snow cover decline of $\sim 16 \%$ over the entire Himalayan region is reported (Menon et al., 2010). Past snow accumulation/snow-fall rates derived from the icecore studies suggest a decline since mid- $20^{\text {th }}$ century (Thompson et al., 2000) while others show an increase (Kaspari et al., 2008). The difference in these records are attributed to differences in moisture trajectories, ice-flow dynamics and inaccuracies in identifying the annual layers (Kaspari et al., 2008). However, most of these studies have been carried out in Tibet (Thompson et al., 2000), very few in Himalayas (Kaspari et al., 2008). Some trends on the seasonal snow cover, specifically for the Indian Himalayan region (IHR) were reported by Kulkarni et al. (2010) using Advanced Wide Field Sensor (AWiFS) of Indian Remote Sensing Satellite (IRS). Snow cover products were generated individually for the 28 sub-basins extending over Indus, Chenab, Ganga and Yamuna basins Satuj basins. These products were used to estimate snow extent at an interval of 10 days from October 2004 to June 2005 using the Normalized Difference Snow Index (NDSI) algorithm. The distribution of snow in an individual basin was combined to estimate the overall snow cover for the Western and Central Himalaya. In the winter of 2004 and 2005, for a period between October and midDecember, snow cover was less than 50 percent and increased to $82 \%$ by the end of January. Snow extent remained more than $80 \%$ till beginning of April. Then snow ablation and retreat of snow cover continued till end of June and residual snow cover remains was only $37 \%$ (Kulkarni et al., 2010).

As monitoring has gained pace, some clear trends are witnessed in annual averages. Increasing/ decreasing snow-cover trend over the entire Hindu Kush Himalaya was reported during 2000-2010 (Gurung et al., 2011). During same period increasing/ decreasing snow cover trend over the Indus, the Ganga and the Brahmaputra basins is reported (Singh et al., 2014). Statistically insignificant contrasting increase of approximately $2 \%$ of snow cover in three sub-basins of Alaknanda and Bhagirathi and 1\% for Yamuna sub-basin is reported (Rathore et al., 2015) whereas Mukhopadhyay (2013) has shown approximately $\sim 32 \%$ increase of snow cover over sub-basin during 1980-2010 which remained stable during 2000-2010.

Recent studies have found that the snow albedo, which depends largely on the SLA (Snow Line Altitude) and snow cover state, has been declining suggesting the darkening and shrinking of snow cover (Ming et al., 2012; Yasunari et al., 2010; Brun et al., 2015). Darkening of snow cover leading to decreased snow albedo has been largely linked with deposition of black carbon (BC). Simulation studies have reported that the enhanced black carbon (BC) over Indian subcontinent contributed $436 \%$ to the decline in snow cover between 1990 and 2000 (Menon et al., 2010). Improved modeling studies have led to the understanding that the $\mathrm{BC}$ is instrumental in causing snow retreat and effects are manifested simultaneously through a threefold process: (i) direct atmospheric heating, (ii) darkening of the snow surface, and (iii) the snow albedo feedback leading to the elevation dependent warming (Xu et al., 2016). High-resolution climate model simulations from 1861 to 2100 reveal a stable snowfall trend for western (supporting the 'Karakoram anomaly') while a decreasing trend is found for central and eastern Himalayan regions (Kapnick et al., 2014). They suggest a meteorological mechanism for the observed and projected regional differences in the snow-ice shrinkage to climate warming.

\section{Peep into Cryospheric Studies in Antarctica: NCAOR}

The research directions and emerging results in Antarctic cryospheric studies by Indian scientists can be grouped into following 3 topics.

\section{Ice Core Palaeo-Climatology}

Ice core based reconstruction of past climate by the Indian scientists revealed significant changes in Southern Hemispheric climate during the past several hundreds of years (Laluraj et al., 2014; Thamban et 
al., 2011, 2013; PAGES 2k Consortium, 2013, 2017; Rahaman et al., 2016). Nitrate $\left(\mathrm{NO}_{3}{ }^{-}\right)$profile in a core revealed a close relationship with the Antarctic

${ }^{10} \mathrm{Be}$ record (solar proxy), suggesting the influence of external solar forcing on the circulation pattern over the Antarctica (Laluraj et al., 2011). The oxygen isotope $\left(\delta^{18} \mathrm{O}\right)$ records of a core supported significant changes in temperature during periods of solar activity as well a warming trend of $2.7^{\circ} \mathrm{C}$ for the past 470 years, with an enhanced warming during the last several decades (Thamban et al., 2011, 2013). Ice core based temperature reconstructions during the past five centuries also revealed substantial warming by $0.6-1^{\circ} \mathrm{C}$ per century, with greatly enhanced warming during the last few decades $\left(\sim 0.4^{\circ} \mathrm{C}\right.$ per decade) (Thamban et al., 2013).

The dust record of IND-25/B5 ice core showed dust deposition in East Antarctica following the Southern Hemispheric climate change, which has doubled during the $20^{\text {th }}$ century (Laluraj et al., 2014). Strong positive correlation observed between ice core dust flux and the Southern Annular Mode (SAM) revealed that the positive values of the SAM index are indicative of increase in dust deposition over East Antarctica, through strengthening of westerly winds. Interestingly, the timing and amplitude of the insoluble dust flux matched remarkably well with the trace metal fluxes of $\mathrm{Ba}, \mathrm{Cr}, \mathrm{Cu}$, and $\mathrm{Zn}$, confirming that dust was the main carrier of airborne geochemical tracers to East Antarctica in the recent past (Laluraj et al., 2014). The observed doubling of dust and associated trace metal deposition in East Antarctica have wideranging implications for understanding the factors driving the inter-continental transportation of impurities and their environmental impact on Antarctica. Proxy records of sea ice (sea-salt sodium $\left(\mathrm{ss}-\mathrm{Na}^{+}\right.$) and methane sulfonic acid (MSA)) and moisture (deuterium excess (d-excess)) variability of IND-25/ B5 ice core also revealed the history of moisture transport and sea ice condition during the last century (Rahaman et al., 2016). This study suggested that moisture source and sea ice variability in annualdecadal scale in Antarctica seems to be largely influenced by SAM and its teleconnection to ENSO.

The ice core studies by NCAOR also contributed to the Past Global Changes (PAGES 2k) consortium aimed at reconstructing global temperature database for the past 2000 years (PAGES 2k
Consortium, 2013). Integrating the 692 proxy climate records from 648 locations spreading across all continents and oceans, the study revealed an overall cooling trend across nearly all continents during the last two thousand years. This cooling trend was reversed by distinct warming, beginning in some regions at the end of the 19th century. This database provides a vital resource for climate researchers interested in how the climate has changed from $1 \mathrm{AD}$ to the present (PAGES 2k Consortium, 2017).

\section{Dynamics and Stability of Ice Shelves and Ice Rises}

Ice shelves of Antarctica are rapidly changing and could largely affect the Antarctic ice sheet stability. Ice rises, grounded ice domes, affect ice-shelf stability and are useful sites to investigate the proxy records of Antarctic climate variability. Dronning Maud Land (DML) is characterized by small ice shelves that are punctuated by ice rises. To fill the knowledge gap and to undertake a detailed study of ice shelves and ice rises of coastal DML, an Indo-Norwegian project named MADICE (Mass balance, dynamics, and climate of the central Dronning Maud Land coast, East Antarctica) was initiated between NCAOR and the Norwegian Polar Institute (NPI). MADICE project investigated the ice dynamics, current mass balance, and millennial-long evolution in the coastal region of the central DML coast as well as the past changes in atmospheric and sea ice dynamics in this region, using remote sensing data, geophysical field measurements, and ice core based climate reconstruction.

During the 2016-17 and 2017-18 seasons, joint Indo-Norwegian field campaigns were under taken within the Nivlisen Ice Shelf and adjacent ice rises (Djupranen, Leningradkollen and Kamelryggen). During the 2016-17 campaign, the glaciology team conducted a range of geophysical surveys over five weeks on the Nivlisen Ice Shelf and adjacent Djupranen and Leningradkollen Ice Rises, to examine their dynamics and evolution in the past millennia. The team first made kinematic GPS surveys for 1900 line kilometers over the two ice rises to precisely measure surface elevations. Two types of ice-penetrating radar were deployed to map bed topography and ice stratigraphy. The radar operations were made for 500 line kilometers of deep-sounding radar and 270 line kilometers of shallow-sounding radar over the two 
ice rises, as well as the ice shelf. Along these survey lines, 90 markers were installed and their initial positions were measured using GPS. The campaign successfully collected a range of glaciological data using GPS and radar, and recovered two ice cores at the summits of the ice rises (depth 122 and $51 \mathrm{~m}$, respectively). The second MADICE campaign is currently underway.

\section{Glaciochemical Processes and Biogeochemistry}

To understand the fundamental air-snow transfer processes in Antarctic ice sheet and to improve the utility of the ice cores as reliable climate archives, field measurements and spatially distributed snow sampling along strategically placed transects are also initiated. First results show that unlike the common perception, Antarctica is not chemically pristine as there is supply of various chemical species like the reduced sulfur species such as dimethyl sulfide, oxidizing chemicals such as NOx, nitrate ions, formaldehyde, ozone and hydrogen peroxide as well as halogen-containing compounds due to various atmospheric and oceanographic processes. Chemical and mass concentrations of aerosols revealed that mass concentrations of coarse aerosols increase towards the Antarctic coast (Thakur and Thamban, 2014). While anthropogenic impact is evident within the fine mode aerosols, the marine influence dominated the coarse mode aerosols. Study on the distribution and source pathways of environmentally critical trace metals in coastal Antarctic snow revealed that while contributions from natural sources are still dominant in Antarctica, anthropogenic contamination related to the ever increasing logistic activities is locally significant (Thamban and Thakur, 2012).

Glaciochemical studies on Antarctic snow for the first time also demonstrated the influence of the degree of slope of the ice sheet on the distribution of sea salt ions in Antarctic snow (Mahalinganathan et al., 2012). Among the large variety of particulates in the atmosphere, calcic mineral dust particles have highly reactive surfaces that undergo heterogeneous reactions with nitrogen oxides contiguously. The association between $\mathrm{Ca}^{2+}$, an important proxy indicator of mineral dust and $\mathrm{NO}_{3}$, in Antarctic snow, studied using 41 snow cores ( $\sim 1 \mathrm{~m}$ each) along two coastal-inland transects from the Princess Elizabeth Land and central Dronning Maud Land (cDML) in
East Antarctica, revealed the formation of calcium nitrate in Antarctic atmosphere. The study helped in discovering a strong relation between calcium and nitrate in Antarctic snow and provided clues on the genesis of calcium nitrate in Antarctic snow and ice (Mahalinganathan and Thamban, 2016). Southern South America was identified as the main calcic mineral dust source to the East Antarctica. The study revealed an association between calcium and nitrate occurs due to the formation of calcium nitrate during the long range airborne transport from South America to Antarctica that may significantly influence the total nitrate deposited in Antarctic snow.

\section{Microbial Ecology and Crybiological Processes}

Cryobiological studies carried out by Indian scientists included diverse fields such as: i). Studies on taxonomy and diversity of microbial communities (bacteria, algae, bryophytes, lichens, fungi etc.) in supraglacial environments; ii). Mechanisms of adaptation to extreme environments and response to environmental stress; iii). Search for novel bioactive molecules and novel microbes; iv). Biogeochemical cycling in supraglacial ecosystems. In recent years, research in the field of cryobiology and biogeochemistry in India has gained momentum with new studies focusing not only on the diversity and physiology of cryospheric life forms but also how cryospheric microbial communities might drive the biogeochemical cycles in these regions. Recently, several microbial species have been isolated from Antarctic cryospheric habitats such as snow (Antony et al., 2011) and ice (Antony et al., 2012, Shivaji et al., 2013) and their physiological and metabolic properties studied. Antioxidant enzyme production was observed in an Antarctic bacterium in response to cold stress (Chattopadhyay et al., 2011). Studies at the biochemical and genetic level have provided important insights into the adaptive strategies employed by microorganisms to survive in the extreme habitats characteristic of cryospheric ecosystems (Kulkarni et al., 2014, Singh et al., 2014, Chattopadhyay et al., 2011, Antony et al., 2012). Recently, the draft genome sequence of several microbes from Antarctica such as Psychrobacter aquaticus strain CMS $56^{\mathrm{T}}$ (Reddy et al., 2013), Leifsonia rubra Strain CMS $76 \mathrm{R}^{\mathrm{T}}$ (Pinnaka et al., 2013), and Arthrobacter gangotriensis Strain Lzly ${ }^{\mathrm{T}}$ (Shivaji et al., 2013) have been published. Active microbial communities associated with snow and ice 
sheet surfaces have been found to play an important role in the biogeochemical cycling in supraglacial systems. The scientific studies being carried out by Indian scientists in the realm of cryospheric sciences will contribute significantly to the global community's ongoing efforts to better understand the functioning of cryospheric systems and how they might respond to future changes as a result of climate change.

Biochemical and microbial characteristics of various supraglacial ecosystems such as, snow, meltwater streams, blue ice and cryoconite holes together with their role in biogeochemical cycling on the glacier surface was systematically studied during the past decade. The studies on cryoconite hole and surface snow samples collected from coastal Antarctica has shown that in addition to abundant and diverse microbial populations, supraglacial environments contain a substantial reservoir of organic carbon with inputs from microbial, marine and terrestrial sources (Antony et al., 2014; Samui et al., 2017). In addition, microcosm experiments involving cryoconite hole samples showed that resident microbial communities have good potential to metabolize organic compounds found in the cryoconite hole environment, thereby influencing the water chemistry in these holes.

\section{Research Leads in Cryospheric Studies in Arctic: NCAOR}

The Arctic region is currently one of the fastest warming regions and the pace/magnitude of environmental change are greater in the Arctic than at any other location on the Earth. Moreover, the ocean and sea ice in the Arctic are a crucial part of the global climate machinery, influencing atmospheric and oceanographic processes, and biogeochemical cycles beyond the Arctic region. Considering the importance of a better understanding of the Arctic, the Government of India initiated expeditions to Arctic region in 2007 with significant major long-term scientific initiatives in the Svalbard archipelago. India's permanent research base named 'Himadri' at NyAllesund in Svalbard is operational since 2008. The thrust areas of the research in the Arctic from India are: (a). Atmospheric sciences with special emphasis on the study of aerosols and precipitation; (b). Cryosphere studies on the mass balance of glaciers and chemical characterization of snow; (c). Biogeochemical studies in fjord systems (with respect to long-term monitoring of climate change studies).

The cryospheric studies by Indian scientists in Arctic mainly focus on the sea ice studies, dynamics and mass budget of Arctic glaciers in the context of climate change as well as the microbiological diversity and ecology in the Ny-Alesund region in Svalbard. Estimation of thin ice thickness for coastal polynyas in the Chukchi and Beaufort Seas using the Advanced Microwave Scanning Radiometer-EOS revealed the model error is $1.3 \mathrm{~cm}$ within the thickness range of 1 $10 \mathrm{~cm}$ (Singh et al., 2011). Recently, several microbial species have been isolated from various cryospheric habitats such as snow, ice, and permafrost and cryoconite holes in Svalbard (Singh and Singh, 2011; Srinivas et al., 2012). Many of the isolated strains have been shown to have biotechnological potential (Hatha et al., 2013). For example, observations related to substrate utilization by Arctic fungi indicate their potential to produce industrially important enzymes such as pectinase, phosphatase, protease, urease, esterase, cellulase and amylase (GawasSakhalkar and Singh, 2011).

To better understand the nitrogen and sulphur chemistry at the Arctic air-snow interface, air and snow measurements were carried Ny Alesund, Svalbard using a particulate sampler equipped with denuders and filter packs for simultaneous collection of trace gases $\left(\mathrm{HNO}_{3}, \mathrm{NO}_{2}, \mathrm{SO}_{2}\right.$ and $\left.\mathrm{NO}_{\mathrm{y}}\right)$ and aerosols. The findings provided useful information on the variability of the fundamental chemical processes at the air-snow interface with the changing meteorological conditions (Thakur and Thamban, 2018). The study revealed that inter-conversion of nitrogen and sulfur species between the gas and particulate phases and their interaction with alkaline species influences the acidity of the aerosols and surface snow. Air measurements carried out NyÅlesund, Svalbard, suggested that nitrate-rich aerosols are formed when PAN (peroxy acetyl nitrate) disassociates to form $\mathrm{NO}_{2}$ and $\mathrm{HNO}_{3}$ which further hydrolyzes to form $\mathrm{pNO}_{3}$ (particulate nitrate). The bicarbonates/carbonates of $\mathrm{Mg}^{2+}$ played an important role in neutralization processes of surface snow while the role of NH3 was dominant in aerosol neutralization processes. Chloride depletion in the snow was significant as compared to the aerosols, indicating two important processes, scavenging of coarse sea salt by the snow and gaseous adsorption of $\mathrm{SO}_{2}$ on the 
snow surface.

\section{Way Forward for Future Research}

Critical overview of field as well as satellite based observations support glacier-climate inter-linkage from millennium to inter-annual scale. The accentuated rate of glacier recession over the large of the Indian Himalaya observed during seventies and eighties of the past century favoured global warning to be a major forcing factor controlling the glacier-climate linkages (Raina, 2009; Gaddam et al.2016; Brun, 2015; Bhambri et al., 2011; Kulkarni et al., 2011). However, the present evidences that rate of recession has slowed significantly in the immediate past decade or two is inconsistent with continuing rise in global temperature (Ajai, 2018). Monitoring of snout and climate sensitive AAA index over the past 50 years have shown that while the glaciers in Central and NE Himalaya are continuously retreating, the glaciers in Western Himalaya are marked by advancement or are utmost stationary (Hewitt, 2005; Ganjoo et al., 2014). This Karakoram anomaly had begun to raise question whether glaciers in the western Himalaya defy the global warming (Yadav et al., 2004). It is also now well recognised that glaciers in the Central Himalaya are nourished by southwest monsoon whereas glaciers in the western Himalaya are fed by mid-latitude westerly (Archer, 2001; Treydte et al., 2006). Depending upon the primary source of precipitation and their strong seasonal character permit to view the Himalayan glaciers in two-types: (i) summer accumulation-cum-summer ablation and (ii) winter accumulation-cum-summer ablation. In such scenario, complex spatial and temporal changes manifested by the glaciers in different climatic zones of the Himalaya can qualitatively be attributed to the combined influence of temperature-precipitation inflicted perturbations (Azam et al., 2014; Thayyen et al., 2010. Lack of in-situ measurements of wet precipitation or AWS in Higher Himalaya have, sofar, inhibited numerical quantification of the influence of temperature/precipitation on the health and dynamics of the glaciers. Vertical distribution of accumulation/ablation areas with respect to snow line, modulation of albedo by debris cover, geometry of valley restricting limited exposure to the Sun, radiation from the wall of the valley etc. are identified as additional physical parameters influencing the dynamics of glaciers within the same basin or located in the intra-basins regions (Dobhal et al., 2013, Patel et al., 2016; Sharma et al., 2016). Here again the earlier field experiments were not specifically designed to test the role of additional physical forcing parameters, their numerical and physical validation has remained unexplored. Standard Operational Practice (S.O.P) to be adopted in future research programs should focus on: Establishment of flagship monitoring stations equipped with the Automatic Weather Stations for basin level mountain meteorology, optically sensed water discharge measurements for melt water contribution to hydrology of the region, particle size analyser and automatic sediment samplers for estimate of sediment transfer, steam drill to implant stakes for mass balance studies would be the key facilities. It should also deploy techniques of ground penetrating radar (GPR) and Natural EM Frequency sounder for mapping the bed rock profile, internal structure and thickness of glaciated column, whereas GPS and Total Station and SAR mapping will be helpful in characterizing movement and deep deformation associated with glacier dynamics. Estimate on the thickness of glaciated column would be a value addition to the AAA index as it would provide much better assessment of mass balance from the satellite data. The validation by comparison with field data would facilitate estimation of mass balance studies of glaciers on regional scale. The S.O.P being adopted by the NCAOR in Arctic and Antarctica can be role model for implementation in the Himalaya. The merit of the S.O.P for its duplication in the Himalaya is apparent from results emerging under the project 'HIMANSH', undertaken by the NCAOR. Reconstruction of past climate from Ice cores obtained from strategically located sites would be critical to answer whether the current retreating trends observed in the Himalayan glaciers is a direct consequence of global warming or is a part of long term Quaternary cyclic oscillations. In the holistic glaciological research in the Himalaya, it will be important to induct two new areas, perhaps for the first time: (i) the role of thermal flow from bed rocks to investigate and understand the role of subglacial heat element in glacier dynamics; (ii) deformation and stress fluctuation due to glacial loading/unloading assume even greater significance as resulting additional stresses can derive the already tectonically stressed fault to trigger seismicity. Further institutionalization of glaciology research will boost 
multidisciplinary studies for climate-glacier interlinkages, melt water prediction towards sustained management of water resources for hydro-power generation, livelihood and agriculture development.

\section{Acknowledgements}

Authors place on record their gratitude to INSA for providing the platform to highlight the activities of IUGG in a special volume of PINSA. It is hoped that the volume will serve as reference to researches and students. Dedication and Leadership provided by Dr
Harsh K. Gupta, Chairman, National INSA-IUGG in shaping the volume is acknowledged with gratitude Dr Rasik Ravindra served as mentor all through the compilation of this chapter, his guidance is deeply acknowledged. One of us (BRA) could build courage to compile the chapter because of the whole hearted contributions from Resource persons from number of organisations. The chapter is dedicated to them all for great support. Dr D.P. Dobhal, Mr Tanuj Shukla and Surendra Bhandari, WIHG were helpful at all stages of material compilation and editing.

\section{References}

Arora M K, Shukla A and Gupta R P (2011) Digital image information extraction techniques for snow cover mapping from remote sensing data In: Encyclopaedia of Snow Ice and Glacierspp 213-232 Springer Dordrecht

Azam M, Wagnon P, Ramanathan A, Vincent C, Sharma P and Arnaud Y (2012) From balance to imbalance: a shift in the dynamic behaviour of Chhota Shigri glacier, Himalaya, India Journal of Glaciology 58 315-324

Azam M F, Wagnon P, Vincent C, Ramanathan A L, Favier V, Mandal A and Pottakkal J G (2014) Processes governing the mass balance of Chhota Shigri Glacier (western Himalaya, India) assessed by point-scale surface energy balance measurements The Cryosphere 8 2195-2217, https://doi.org/10.5194/tc-8-2195-2014

Azam M F, Ramanathan A L, Wagnon P, Vincent C, Linda A, Berthier E, Sharma P, Mandal A, Angchuk T, Singh V B and Pottakkal J G (2016) Meteorological conditions, seasonal and annual mass balances of Chhota Shigri Glacier, Western Himalaya, India Annals of Glaciology 57 328338

Bahuguna I M, Rathore B P, Brahmbhatt R, Sharma M, Dhar S, Randhawa S S and Ganjoo R K (2014) Are the Himalayan glaciers retreating? Current Science 106 5-10

Bhambri R, Bolch T, Chaujar R K and Kulshreshta S C (2011) Glacier changes in the Garhwal Himalaya, India, from 1968 to 2006 based on remote sensing J Glaciology 57 543-556

Brun, F, Dumont M, Wagnon P, Berthier E, Azam, M F, Shea J M and Ramanathan A (2015) Seasonal changes in surface albedo of Himalayan glaciers from MODIS data and links with the annual mass balance The Cryosphere 9 341-355

Chattopadhyay M K, Raghu G, Sharma Y V, Biju A $R$, Rajasekharan M V and Shivaji S (2011) Increase in oxidative stress at low temperature in an Antarctic bacterium Curr Microbiol 62 544-546 
Chauhan M S (2006) Late Holocene vegetation and climate change in the alpine belt of Himachal Pradesh Current Science 911562-1567

Dobhal D P, Gergan J T and Thayyen R J (2008) Mass balance studies of Dokriani glacier from 1992 to 2000, Garhwal Himalaya, India Bulletin of Glaciological Research, Japanese Society of Snow and Ice 25 9-17

Dobhal D P, Mehta M and Srivastava D (2013) Influence of debris cover on terminus retreat and mass changes of Chorabari Glacier, Garhwal region, central Himalaya, India Journal of Glaciology 59 961-971

Dong P, Wang C and Ding J (2013) Estimating glacier volume loss using remotely sensed images, digital elevation data and GIS modelling International Journal of Remote Sensing 34 8881-8892

DST (2012) Dynamics of Glaciers in the Indian Himalaya: Science Plan. Prepared by R.K. Midha. Published by the Science and Engineering Board, Department of Science and Technology, New Delhi, Himalayan Glaciology Technical Report No.2 pp 125

Dyhrenfurth G O (1955) The third Pole- The history of the High Himalaya (1st UK Edition). London: Ex Libris, Werner Laurie

Dyurgerov M B and Meier M F (2005) Glaciers and the changing Earth system: a 2004 snapshot Institute of Arctic and Alpine Research, University of Colorado, Boulder 58

Engelhardt M, Ramanathan A, Eidhammer T, Kumar P, Landgren O, Mandal A and Rasmussen R (2017) Modelling 60 years of glacier mass balance and runoff for Chhota Shigri Glacier, Western Himalaya, Northern India Journal of Glaciology63618-628 https://doi.org/10.1017/jog.2017.29

Gaddam V K, Kulkarni A V and Gupta A K (2016) Estimation of glacial retreat and mass loss in Baspa basin, Western Himalaya Spatial Information Research 24 257-266

Gaddam V K, Kulkarni, A V and Gupta A K (2017a) Reconstruction of Specific mass balance for glaciers in Western Himalaya using Seasonal Sensitivity Characteristics Journal of Earth System Science 127 1-12

Gaddam V K, Kulkarni A V and Gupta A K (2017b) Estimation of snow-ice melt and rainfall contribution to Baspa river runoff in Western Himalaya Environmental Monitoring and Assessment, Springer doi: 10.1007/s10661-017-63499

Ganjoo R K, Koul M N, Bahuguna I M and Ajai (2014) The Complex Phenomenon of Glaciers of Nubra Valley Karakorum (Ladakh) India Natural Science 6 733-740

Gasse F, Téhet R, Durand A, Gibert E and Fontes J C (1990) The arid-humid transition in the Sahara and the Sahel during the last deglaciation Nature 346 141-144

Gawas-Sakhalkar P and Singh S M (2011) Fungal community associated with Arctic moss, Tetraplodon mimoides and its rhizosphere: bioprospecting for production of industrially useful enzymes Current Science 100 17011705.

Goel P S, Ravindra R and Chattopadhyay S (Eds) (2018) Science and Geopolitics of the white world Arctic, Antarctic and Himalaya (SaGAA) pp 216 Springer

GRIP Members (1993) Green land Ice core Project. Climate instability during the last inter-glacial period recorded in the GRIP ice core Nature 364 203-207

Guenni L and Hutchinson M F (1998) Spatial interpolation of the parameters of a rainfall model from ground-based data Journal of Hydrology 212 335-347

Gurung D R, Giriraj A, Anug K S, Shreshtha B and Kulkarni A V (2011) Snow-cover mapping and monitoring in the Hindu Kush-Himalayas, Kathmandu, Nepal: ICIMOD, pp 32

Hasson S, Lucarini V, Khan M R, Petitta M, Bolch T and Gioli G (2014) Early 21 st century snow cover state over the western river basins of the Indus River system Hydrology and Earth System Sciences 18 4077-4100

Hatha AA M, Rahiman M, Krishnan K P, Saramma AV, Saritha G and Lal D (2013) Characterisation and bioprospecting of cold adapted yeast from water samples of Kongsfjord, Norwegian Arctic Indian Journal of Geo Marine Sciences 42 458-465

Hewitt K (2005) The Karakoram Anomaly? Glacier expansion and the 'Elevation Effect', Karakoram Himalaya Mountain Research and Development 25 332-340

Houghton J T, Ding Y D J G, Griggs D J, Noguer M, van der Linden P J, Dai X and Johnson, C A (2001) Climate change 2001: the scientific basis. The Press Syndicate of the University of Cambridge.

Immerzeel W W, Droogers P, de Jong S M and Bierkens M F P (2009) Large-scale monitoring of snow cover and runoff simulation in Himalayan river basins using remote sensing Remote Sens Environ 113 40-49, doi: 10.1016/ j.rse.2008.08.010

IAHS (ICSI)-UNEP-UNESCO(1989) World glacier inventory: status 1988. Paris. Eds. Haeberli W, Bösch H, Scherler K, Østrem $\mathrm{G}$ and Wallén C C

IPCC (2007) Summary for policymakers. In: Climate Change (2007); The Physical Science Basis, Contribution of Working Group I to the Fourth Assessment Report of the Intergovernmental Panel on Climate Change. Eds: Solomon S, Qin D, Manning M, Chen Z, Marquis M, Averyt KB, Tignor M, Miller HL). Cambridge University Press, 
Cambridge, United Kingdom and New York, NY, USA

IPCC (2014) Climate Change 2014: Synthesis Report. Contribution of Working Groups I, II and III to the Fifth Assessment Report of the Intergovernmental Panel on Climate Change In;(Core Writing Team, Eds R K Pachauri and L A Meyer. IPCC, Geneva, Switzerland. http:// www.ipcc.ch/ report/ar5/syr

Jain S K and Kumar V (2012) Trend analysis of rainfall and temperature data for India Current Science 102 37-49

Joshi R, Kireet Kumar, Jibotosh Pandit and Palni L M S (2015) Variations in the Seasonal Snow Cover Area (SCA) for Upper Bhagirathi Basin, India, Dynamics of Climate Change and Water Resources of Northwestern Himalaya, Society of Earth Scientists Series XII 204-221, DOI 10.1007/978-3-319-13743-8

Kapnick S B, Delworth T L, Ashfaq M, Malyshev S, Milly P C D (2014) Snowfall less sensitive to warming in Karakoram than in Himalayas due to a unique seasonal cycle Nature Geosci 7 834-840

Kaspari S, Hooke R L, Meyewski P A, Kang S, Hou S and Qin D (2008) Snow accumulation rate on Qomolangma (Mount Everest), Himalaya: synchroneity with sites across the Tibetan Plateau on 50-100 year timescales Journal of Glaciology 54 343-352

Kaul M K and Puri V M K (1999) Inventory of the Himalayan glaciers: a contribution to the International Hydrological Programme Geological Survey of India pp158

Khan A A, Pant N C, Sarkar A, Tandon S K, Thamban M and Mahalinganathan K (2017) The Himalayan cryosphere: A critical assessment and evaluation of glacial melt fraction in the Bhagirathi basin Geoscience Frontiers 8 107-115

Khan AA, Pant N C, Ravindra R, Alok A, Gupta M and Gupta S (2018) A precipitation perspective of the Hydrospherecryosphere interaction in the Himalaya Geological Society London Special Publications pp 462 https://doi.org/ 10.1144/SP462.2

Konz M, Finger D, Buergi C, Normand S, Immerzeel W W, Merz J, Giriraj A and Burlando P (2010) Calibration of a distributed hydrological model for simulations of remote glacierised Himalayan catchments using MODIS snow cover data In: Global Change: Facing Risks and Threats to Water Resources International Association of Hydrological Sciences (IAHS) Publication 340 465-473 Walling -Ford, UK

Kriplani R H, Kulkarni A and Sabade S S (2003) Western Himalayan snow cover and Indian monsoon rainfall: A re-examination with INSAT and NCEP/NCAR data Theoretical and Applied Climatology 74 1-18
Kulkarni A V (1992) Mass balance of Himalayan glaciers using AAR and ELA methods Journal of Glaciology 38 101104

Kulkarni A V, Rathore B P, Singh S K and Ajai (2010) Distribution of Seasonal snow cover in Central and Western Himalaya Annals of Glaciology 51 123-128

Kulkarni A V, Rathore, B P, Singh S K and Bahuguna I M (2011) Understanding changes in the Himalayan cryosphere using remote sensing techniques International Journal of Remote Sensing 32 601-615

Kulkarni H M, Swamy Ch V and Jagannadham M V (2014) Molecular characterization and functional analysis of outer membrane vesicles from the Antarctic bacterium Pseudomonas syringae J Proteome Res 131345-1358

Laluraj C M, Thamban M and Satheesan K (2014) Dust and associated geochemical fluxes in an ice core from the coastal East Antarctica and its linkages with Southern hemisphere climate variability Atmospheric Environment 90 23-32

Laluraj C M, Thamban M, Naik S S, Redkar B L, Chaturvedi A and Ravindra R (2011) Nitrate records of a shallow ice core from East Antarctica: atmospheric processes, preservation and climatic implications The Holocene 21 351-356

Mahalinganathan K, Thamban M, Laluraj C M and Redkar B L (2012) Relation between surface topography and sea-salt snow chemistry from Princess Elizabeth Land, East Antarctica The Cryosphere 6 505-515

Mahalinganathan K and Thamban M (2016) Potential genesis and implications of calcium nitrate in Antarctic snow The Cryosphere 10 825-836

Mandal A, Ramanathan A L and Angchuk T (2014) Assessment of Lahaul-Spiti (western Himalaya, India) Glaciers-An Overview of Mass Balance and Climate Journal of Earth Science \& Climatic Change 2 S11-001

Maurya A S, Shah M, Deshpande R D, Bhardwaj R M, Prasad A and Gupta SK (2011) Hydrograph separation and precipitation source identification using stable water isotopes and conductivity: River Ganga at Himalayan foothills Hydrological Processes 25 1521-1530

Mazari R K, Bagati, T N, Chauhan, M S and Rajagopalan G (1996) Palaeoclimatic and environmental variability in Austral-Asian Transact during the past 2000 years. Proceedings IGBP-PAGES-PEPII Symposium, Nagoya, Japan, 262-269

Meier M F and Post A S (1962) Recent variations in mass net budgets of glaciers in western North America IASH Publ 58 63-77

Menon S, Koch D, Beig G, Sahu S, Fasullo J and Orlikowski D 
(2010) Black carbon aerosols and the third polar ice cap Atmospheric Chemistry and Physics 10 4559-4571

Ming J, Du Z, Xiao C, Xu X and Zhang D (2012) Darkening of the mid-Himalaya glaciers since 2000 and the potential causes Environ Res Lett 7014021 pp13

Mukhopadhyay B (2013) Signature and hydrologic consequences of climate change within the upper-middle Brahmaputra Basin Hydrological Processes 27 2126-2143

Nainwal H C, Chaudhary M, Rana N, Negi, B D S, Negi R S, Juyal N and Singhvi A K (2007) Chronology of the Late Quaternary glaciation around Badrinath (upper Alaknanda Basin): preliminary observations Current Science 93 9096

Owen L A, Debyshire E and Fort M (1998) The Quaternary glacial history of the Himalaya. In Owen L.A. (Ed.), Mountain Glaciation. Quaternary Proceedings, Wiley, Chichester 6, 91-120

Owen L A, Gualtieri L Y N, Finkel R C, Caffee M W, Benn D I and Sharma M C (2001) Cosmogenic radionuclide dating of glacial landforms in the Lahul Himalaya, northern India: defining the timing of Late Quaternary glaciation $J$ Quaternary Sci 16 555-563

Pages 2k Consortium (2013) Continental-scale temperature variability during the last two millennia Nature Geoscience doi: 10.1038/NGEO1797

Pages 2k Consortium (2017) A global multi-proxy database for temperature reconstructions of the Common Era Scientific Data 4:170088 doi:10.1038/sdata.2017.88

Pant N C, Ravindra R, Srivastava D and Thompson L G (eds) (2018) The Himalayan Cryosphere: Past and Present. Geological Society, London, Special Publications 462 doi.org/10.1144/SP462.13

Patel L K, Sharma P, Laluraj C M, Thamban M, Singh A T and Ravindra R (2016) A geospatial analysis of Samudra Tapu and Gepang Gath glacial lakes in the Chandra basin, Western Himalaya Natural Hazards doi:10.1007/s11069017-2743-4

Paterson, W S B (1994) The Physics of Glaciers. 3rd Edition Pergamon, Oxford, pp 480

Patwardhan A and Members (2010) Report of the Study Group on Himalayan Glaciers, Published by the Principal Scientific Advisor, Government of India, pp.140

Pinnaka A K, Singh A, Ara S, Begum Z, Reddy G S and Shivaji S (2013) Draft genome sequence of Leifsonia rubra strain CMS $76 \mathrm{R}^{\mathrm{T}}$, isolated from a cyanobacterial mat sample from a pond in Wright Valley, McMurdo Antarctica Genome Announc1 e00633-13. doi: 10.1128/genome
A.00633-13

Pratap B, Dobhal D P, Mehta M and Bhambri R (2015) Influence of debris cover and altitude on glacier surface melting: a case study on Dokriani Glacier, central Himalaya, India Annals of Glaciology 56 9-16

Qiu J (2008) China: the third pole Nature News 454 393-396

Rahaman W, Thamban M and Laluraj C M (2016) Twentieth Century sea ice variability in the Weddell Sea and its effect on moisture transport: Evidence from a coastal East Antarctic ice core record The Holocene DOI: 10.1177/ 0959683615609749

Raina V K (2009) A state-of-art review of glacial studies, glacial retreat and climate change. Discussion Paper, New Delhi: MOEF, 2009

Raina V K and Srivastava D (2008) Glacier atlas of India Geol Soc India, Bangalore, Publications 7

Raina V K, Kaul M K and Singh S (1977) Mass balance of the Gara Glacier for 197475 Journal of Glaciology 18 415423

Ramanathan A L (2011) Status Report on Chhota Shigri Glacier (Himachal Pradesh). Department of Science and Technology, Ministry of Science and Technology, New Delhi Himalayan Glaciology Technical Report Number 1 pp 88

Rathore B P, Singh S K, Bahuguna I M, Brahmbhatt R M, Rajawat AS, Thapliyal A, Panwar A and Ajai (2015) Spatio-temporal variability of snow cover in Alaknanda, Bhagirathi and Yamuna sub-basins, Uttarakhand Himalaya Current Science 108 1375-1380

Ravindra R and Laluraj C M (2012) Cryosphere Research: Indian Perspective Proc Indian Natn Sci Acad 78 249-257

Reddy G S, Ara S, Singh A, Pinnaka K A and Shivaji S (2013) Draft genome sequence of Psychrobacter aquaticus strain CMS $56^{\mathrm{T}}$, isolated from a cyanobacterial mat sample collected from water bodies in the McMurdo dry valley region of Antarctica Genome Announc 1: e00918-13. doi:10.1128/genomeA.00918-13

Rikiishi K and Nakasato H (2006) Height dependence of the tendency for reduction in seasonal snow cover in the Himalaya and the Tibetan Plateau region, 1966-2001 Annals of Glaciology 43 369-377

Rühland K, Phadtare N R, Pant R K, Sangode S J and Smol J P (2006) Accelerated melting of Himalayan snow and ice triggers pronounced changes in a valley peat land from northern India Geophys Res Letts 33L15709 doi:10.1029/ 2006GL026704

Samui G D, Antony R, Mahalinganthan K and Thamban, M 
(2017) Spatial variability and possible sources of Acetate and Formate in the surface snow of East Antarctica Journal of Environmental Sciences 57 258-269

Sangewar C V and Shukla S P (2009) In; Inventory of Himalaya glaciers (Eds), Geo Surv Ind Spl Pub 34

Schulz H, von Rad U and Erlenkeuser H (1998) Correlation between Arabian Sea and Greenland climate oscillations of the past 110,000 years Nature 393 54-57

Sharma A K, Singh S and Kulkarni A V (2008) Approach for Himalayan Glacier Inventory using remote sensing and GIS techniques. In: Venkataraman G, Nagarajan R (eds) Proceedings of International Workshop on Snow, Ice, Glacier and Avalanches. IIT-B. Tata McGraw-Hill Publishing Company Ltd, New Delhi, pp 177-185

Sharma A K, Singh S K, Kulkarni A V and Ajai (2013a) Glacier Inventory in Indus, Ganga and Brahmaputra Basins of the Himalaya National Academy Science Letters 36 497- 505

Sharma M C and Owen LA (1996) Quaternary glacial history of NW Garhwal, Central Himalayas Quaternary Science Review 15 335-365

Sharma M C and Chand P (2016) Studies on Quaternary Glaciations in India During 2010-2016 Proc Indian Natn Sci Acad 82 869-880 DOI: 10.16943/ptinsa/2016/48490

Sharma P, Ramanathan A L and Pottakkal J (2013b) Study of solute sources and evolution of hydrogeochemical processes of the Chhota Shigri Glacier melt waters, Himachal Himalaya India Hydrological Sciences Journal 58 1128-1143

Sharma P, Patel L K, Ravindra R, Singh A T, Mahalinganathan K and Thamban M (2016a) Role of debris cover to control specific ablation of adjoining Batal and Sutri Dhaka glaciers in Chandra Basin (Himachal Pradesh) during peak ablation season Journal of Earth System Science 125 459-473

Sharma S, Chand P, Bisht P, Shukla A D, Bartarya S K, Sundriyal Y P and Juyal N (2016b) Factors responsible for driving the glaciation in the Sarchu Plain, eastern Zanskar Himalaya, during the late Quaternary J Quat Sci 31 495511

Shivaji S, Ara S, Bandi S, Singh A and Pinnaka K A (2013) Draft genome sequence of Arthrobacter gangotriensis strain $\mathrm{Lzly}^{\mathrm{T}}$, isolated from a penguin rookery soil sample collected in Antarctica, near the Indian station Dakshin Gangotri Genome Announc 1 e00347-13. doi:10.1128/ genomeA.00347-13

Singh J and Yadav R R (2005) Spring precipitation variations over the western Himalaya, India, since AD 1731 as deduced from tree rings $J$ Geophys Res 110 D01110 doi:10.1029/ 2004JD004855
Singh A K, Sad K, Singh S K and Shivaji S (2014) Regulation of gene expression at low temperature: role of cold-inducible promoters Microbiology $\mathbf{1 6 0} 1291-1297 \mathrm{https}$ :// doi:10.1099/mic.0.077594-0

Singh A T, Laluraj C M, Sharma P, Patel L K and Thamban M (2017) Export fluxes of geochemical solutes in the meltwater stream of Sutri Dhaka Glacier, Chandra basin, Western Himalaya Environmental Monitoring and Assessment 189 555-563

Singh R K and Sagewar C V (1989) Mass balance variation and its impact on glacier flow movement at Shaune Garang glacier, Kinnaur, HP Proceedings of the National Meet on Himalayan Glaciology pp1499

Singh V B and Ramanathan A (2015) Assessment of solute and suspended sediments acquisition processes in the Bara Shigri glacier meltwater (Western Himalaya, India) Environmental Earth Sciences 74 2009-2018 https:// doi.org/10.1007/s12665-015-4584-3

Singh V B and Ramanathan A L (2017) Characterization of hydrogeochemical processes controlling major ion chemistry of the Batal glacier melt water, Chandra Basin, Himachal Pradesh, India Proceedings of the National Academy of Sciences, India Section A: Physical Sciences 87 145-153

Singh V B, Ramanathan A, Mandal A and Angchuk T (2015).Transportation of Suspended Sediment from Melt water of the Patsio Glacier, Western Himalaya, India Proceedings of the National Academy of Sciences, India Section A: Physical Sciences 85 169-175 https:// doi.org/10.1007/s40010-015-0198-0

Singh V B, Ramanathan A L, Pottakkal J G and Kumar M (2014) Seasonal variation of the solute and suspended sediment load in Gangotri glacier melt water, central Himalaya, India Journal of Asian Earth Sciences 79 224-234

Singh V B, Ramanathan A and Pottakkal J G (2016) Glacial runoff and transport of suspended sediment from the Chhota Shigri glacier, Western Himalaya India Environmental Earth Sciences 75695 doi.org/10.1007/s12665-016-52718

Singh P and Singh S M (2011) Characterization of yeast and filamentous fungi isolated from cryoconite holes of Svalbard, Arctic Polar Biology 35 575-583

Singh S M, Singh P and Ravindra R (2011) Screening of Antioxidant Potential from Arctic Lichens Polar Biology DOI 10.1007/ s00300-011-1027-9

Srinivas T N R, Vardhan Reddy P V, Begum Z, Manasa P and Shivaji S (2011) Oceanisphaera arctica sp. nov., isolated from a marine sediment of Kongsfjorden, Svalbard Arctic 
Int J Syst Evol Microbiol 61 1762-1762 doi:10.1099/ ijs.0.024539-0

Srinivas T N R, Singh S M, Pradhan S, Pratibha M S, Kishore K H, Singh A K, Begum Z, Prabagaran S R, Reddy G S N and Shivaji S (2011) Comparison of bacterial diversity in proglacial soil from Kafni Glacier, Himalayan Mountain ranges, India, with the bacterial diversity of other glaciers in the world Extremophiles 15 673-690

Thakur R C and Thamban M (2014) Latitudinal and size segregated compositional variability of aerosols over the Indian and Southern Ocean during 2010 austral summer Aerosol and Air Quality Research 14 220-236

Thakur R C and Thamban M (2018) Influence of gaseous and particulate species on neutralization processes of polar aerosol and snow - A case study from Ny-Ålesund Journal of Environmental Sciences https://doi.org/10.1016/j.jes. 2018.03. 002

Thamban M, Laluraj C M, Naik S S and Chaturvedi A (2011) Reconstruction of Antarctic climate change using ice core proxy records from the coastal Dronning Maud Land, East Antarctica Journal of Geological Society of India 78 19-29

Thamban M and Thakur R C (2012) Trace metal concentrations of surface snow from Ingrid Christensen Coast, East Antarctica-spatial variability and possible anthropogenic contributions Environmental Monitoring and Assessment 185 2961-2975

Thamban M, Naik S S, Laluraj C M, Chaturvedi A and Ravindra $\mathrm{R}$ (2013) Antarctic climate variability during the past few centuries based on ice core records from coastal Dronning Maud Land and its implications on the recent warming. In: Earth System Processes and Disaster Management Springer Berlin Heidelberg pp. 51-66

Thayyen R J and Gergan J T (2010) Role of glaciers in watershed hydrology: a preliminary study of a "Himalayan catchment" The Cryosphere 4 115-128
Thompson L G, Yao T, Thompson M, Davis M E, Henderson K A and Lin P N (2000) A high-resolution millennial record of the South Asian monsoon from Himalayan ice cores Science 289 1916-20

Treydte K S, Schleser G H, Helle G, Frank D C, Winger M, Huag G H and Esper J (2006) The twentieth century was the wettest period in northern Pakistan over the past millennium Nature 440 1179-1182, doi : 10.1038/ nature 04743

UNESCO (1970) Combined Heat, Ice and Water Balance at Selected Glacier Basins: A Guide to Measurement and Data Compilation Tech Paper in Hydrology No. 5

Venkatesh T N, Kulkarni A L and Srinivasan J (2012) Relative effect of slope and doi:10.5194/tc-6-301-2012

Vohra C P (1981) Himalayan glaciers. In: Himalayan aspects of change Eds Lall J S and Maddie A D, Oxford University Press, Delhi, 138-151

World Glacier Monitoring Service (WGMS) (1989) World glacier inventory: status 1988, Eds. Haeberli W, Bo“sch H, Scherler $\mathrm{K}$, Østrem $\mathrm{G}$ and Walle'n C C. IAHS(ICSI)-UNEPUNESCO, World Glacier Monitoring Service, Zürich

Xu Y, Ramanathan V and Washington W M (2016) Observed high-altitude warming and snow cover retreat over Tibet and the Himalayas enhanced by black carbon aerosols Atmos Chem Phys 16 1303-1315

Yadav R R, Park W K, Singh J and Dubey B (2004) Do the western Himalayas defy global warming? Geophysical Research Letters 31 L17201 doi: 10.1029/2004GL02020

Yasunari T J, Bonasoni P, Laj P, Fujita K, Vuillermoz E, Marinoni A, Cristofanelli P, Duchi R, Tartari G and Lau K-M (2010) Estimated impact of black carbon deposition during premonsoon season from Nepal Climate Observatorypyramid data and snow albedo changes over Himalayan glaciers Atmos Chem Phys 10 6603-15. 